\title{
APPRISING THE LOCAL AND GLOBAL IMPLICATION OF AMBIENTAIR QUALITY INDEX OF KADUNA METROPOLIS, NIGERIA
}

\author{
Daful, Mwanret Gideon ${ }^{A}$, Adewuyi, Taiye Oluwafemi ${ }^{A}$, \\ Dadan-Garba, Aliyu' ${ }^{A}$, Oluwole, Olumide Akinwumi ${ }^{A}$, \\ Muhammad, Muktar Namadi ${ }^{B}$ and Ezeamaka, Cyril Kanayochuku \\ Received: May 6, 2020 | Accepted: June 10, 2020 \\ DOI: 10.5937/ZbDght2001022D
}

\begin{abstract}
This study apprises the local and global implication of ambient air quality index of Kaduna Metropolis, Nigeria. With the point of investigating the spatial and transient dissemination of the Air Quality Index (AQI) of Carbon monoxide (CO), Sulfur dioxide $\left(\mathrm{SO}_{2}\right)$, and Particulate Matter $\left(P \mathrm{M}_{10}\right)$ and their suggestions on human wellbeing, in view of neighborhood and global measures. Data were collected during the raining season and dry harmattan weather. From traffic, Industrial, commercial and residential areas, utilizing validated portable pollutant monitors (MSA Altair $5 x$ Gas Detector ${ }^{a}$ ) to collect data on the concentration of air pollutants ( $\mathrm{CO}$ and $\left.\mathrm{SO}_{2}\right)$ and (CW-HAT2OO Particulate Counter) for the concentration of particulate matters (PM 10$)$. Equal allocation stratify sampling and purposive sampling were utilized for the selection of sample points. The data were analyzed in line with USEPA Air Quality Index calculation approach and using descriptive statistics. The findings reveal that the AQI of Kaduna Metropolis ranges from good to hazardous, CO has $57.57 \%$ and $24.24 \%$ of the sample sites AQI ranging from unhealthy to hazardous based on WHO/USEPA and NESREA standards respectively. Equally $\mathrm{SO}_{2}$ has about $91 \%, 34.23 \%, 42.42 \%$ of the sites $A Q I$ ranging from unhealthy to hazardous base on WHO, USEPA and NESREA standards respectively. PM 10 has $75.76 \%$ and 18.18 of the sites AQI as hazardous base on WHO and USEPA standards, whereas none of the sites AQI is hazardous base on the NESREA standard. Further analysis shows that the northern part of the metropolis has more sites with unhealth AQI than the southern part of the metropolis. Also, the traffic land use has more of its sites AQI ranging from unhealthy to Sensitive group to hazardous. In conclusion this study provides empirical data on the AQI of Kaduna metropolis which ranges from good to hazardous. Thus, the need for the enforcement agencies to strictly enforce the guide lines regulating ambient pollution in the study area.
\end{abstract}

Keywords: Air Pollutants, Air Quality Index, Urban Land Used, Human Health

A Department of Geography, Nigerian Defence Academy Kaduna, Nigeria; corresponding author: mwanret.daful@nda.edu.ng

B Department of Chemistry, Nigerian Defence Academy Kaduna, Nigeria 


\section{INTRODUCTION}

Air is one of the most important constituents of man's environment. An average human being requires about $12 \mathrm{~kg}$ of air each day, which is nearly 12 to 15 times greater than the amount of food consumed (Garg, Garg, and Garg, 2006; Ladan, 2013). Clean and pure air is very essential for human health and survival. Any change in the natural or normal composition of air that may adversely affects the living system, particularly the human life invariably causes air pollution (Garg et al., 2006).The air that we breathe daily is comprised of $21 \%$ oxygen and $78 \%$ nitrogen, with the remainder consisting of trace amounts of rare gases (David and Frederikse, 1997; Delay and Zanetti, 2007; Augustine, 2012; Aremu, 2014).

Air pollution is generally regarded as the presence in the atmosphere of one or more contaminants such as fumes, dust, gases, mist, odour, smoke, smog or vapours in considerable quantities and duration of which is injurious to human, animal and plant life or which unreasonably interferes with the comfortable enjoyment of life and the environment (Odigure, 1998; Anjoneyulu, 2005; Ladan, 2013;Ogwu,Peter,Aliy and Abubakar, 2015). Thus, air pollution is generally disequilibrium condition of air caused by the introduction of foreign elements from natural and man-made sources to the atmosphere so that it becomes injurious to biological communities(Ladan, 2013; Ogwu et al., 2015). The World Health Organization (WHO) defines air pollution as limited to situations in which the outer ambient atmosphere contains materials in concentrations which are harmful to man and his environment (WHO, 2006; Anjoneyulu, 2005 and Ladan, 2013). A substance in the air that can cause harm to humans and the environment is known as an air pollutant and air pollutants are expressed asparts per million ( $\mathrm{ppm}$ ) by volume or micrograms per cubic meter of air (ug/m3) which is subjected to change to variations of temperature and pressure (Das and Behera, 2008).

Air Quality Index (AQI) is an index for reporting daily air quality in the United States (USEPA, 2003). It gives information on how clean or polluted the air is, and what associated health effects might be of concern for individuals (Saniei et al., 2016). Cheng et al. (2007) to convey the air quality status to the scientific community, government officials, policy maker and in particular to the general public in a simple and straightforward manner. The AQI focuses on health effects individuals may experience within a few hours or days after breathing polluted air (Bortnick et al., 2002; USEPA, 2003; Murena, 2004; USEPA, 2014). AQI values below 100 are generally thought of as satisfactory (Mohan and Kandya, 2007). When AQI values are above 100, air quality is considered to be unhealthy, at first for certain sensitive groups of people, then for everyone as the AQI values get higher (Mintz, 2009).

Spatio-temporal analysis and modelling address problems that are spatially distributed (Zeiler, 2010) as well as temporally related (Jorgensen and Bendoricchio, 2001). The two basic methodologies addressing these dimensions are spatial databases managed by the Geographic Information System (GIS) and dynamic models processed by simulation tools on the other hand (Maquire, Batty and Goodchild, 2005;Matejicek, 2011) an additional dimension is added by integration with the monitoring data (Fedra, 1999).In Nigeria, air pollution has become a topic of intense debate at all levels because of the enhanced 
anthropogenic activities. Urban air pollution in Nigeria has increased rapidly with population growth, numbers of motor vehicles, use of fuels with poor environmental performance, badly maintained transportation systems and above all, ineffective environmental regulations (Gupta, Karar, Ayoob, and John 2008; Olajire et al., 2011; Yusuf et al., 2013).

In spite of increasing urban development and anthropogenic activities, monitored data on urban air pollution are sparse in Nigeria and many developing countries (Baumbach et al., 1995; Gupta et al., 2006; Abam and Unachukwu, 2009). The ability to understand the patterns and magnitude of pollution in the urban environment is increasingly important (Smallbone, 1998; Mwenda, 2011). Maps are needed, equally, to inform environmental managers, town planners and policy makers on the magnitude and pattern of the pollutants. This will aid in the mitigation, management and control of the pollutants. Hence, for the benefit of public health and sustainability of the natural functioning of ecosystems it is necessary to carry out a study like this which aims to analyzed the spatial and temporal distribution of Air Quality Index (AQI) in Kaduna metropolis.

\section{METHODS}

\section{The Study Area}

Kaduna metropolis is the capital of Kaduna State. The State is located almost at the mid-central portion of the Northern parts of Nigeria and shares common borders with Zamfara (NW), Katsina (N), Niger (SW), Kano (NE), Bauchi (NE), Nasarawa (S), Plateau (SE) States, and the Federal Capital Territory to the South (Nwude, 2006). Kaduna metropolis is located between Latitudes $10^{\circ} 24^{\prime} 39^{\prime \prime} \mathrm{Nand} 10^{\circ} 36^{\prime} 40^{\prime \prime} \mathrm{N}$ and Longitudes $7^{\circ} 21^{\prime} 26^{\prime \prime} \mathrm{E}$ to $7^{\circ} 30^{\prime} 3^{\prime \prime} \mathrm{E}$ of the Greenwich meridian on the high plains of the north central highlands of Nigeria (Figure 1), with a mean elevation of about $620 \mathrm{M}$ amsl. It covers more than 355 square kilometers, Kaduna metropolis is about $912 \mathrm{Km}$ north of the Gulf of Guinea (Atlantic Ocean), about $530 \mathrm{Km}$ from Nigeria's northern border and $180 \mathrm{Km}$ from the nation's capital city, Abuja. The River Kaduna from which the town derived its name tends to divide the town into two unequal parts. Kaduna metropolis cut across four local governments areas in the state thus: Kaduna North, Kaduna South as well as parts of Igabi and Chikun Local Government Areas (LGAs) (Akpu, 2012).

Kaduna metropolis experienced tropical continental climate with distinct seasonal regimes. The seasonality is characterized with the cool and hot dry season. The climate is also characterized between November and March by dust laden harmattan and wind, which is dry cold and often strong blocks, from north-east originating from the Sahara region across the country with maximum intensity between December and January. The area is influenced by the tropical wet and dry climate (AW by Koppen's classification) with seasonal alternation of moist maritime air mass (tropical maritime/SW trade wind), and dry continental air mass (North easterly trade wind/hamattan) (Abaje, Ati, and Ishaya, 2009). The climatic classification of the study area is the tropical continental climate. It is characterized by two distinct alternating wet and dry seasons. The rainy 


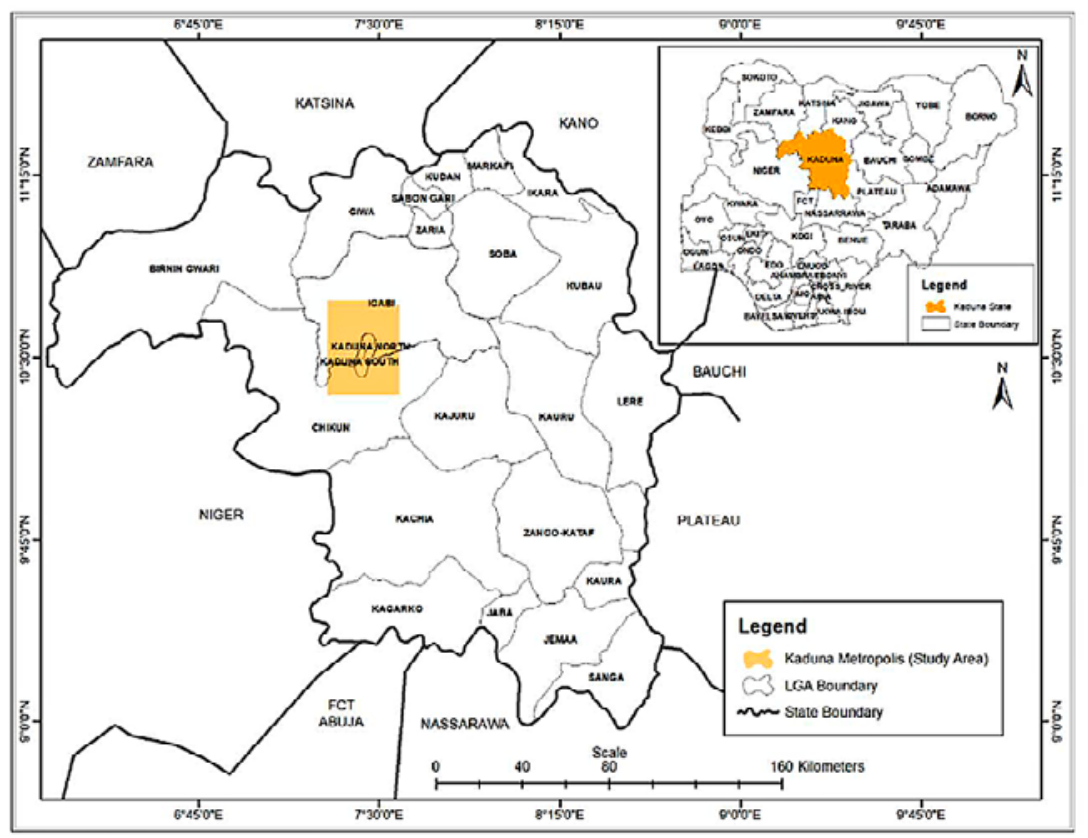

Figure 1: Kaduna Metropolis in Kaduna State Source: KADGIS (2017)

season usually begins from March/April and runs through September/October. Rainfall begins in April and increases to its peak in August. The rainy season is associated with high intensity of storm and by October, the rain declines. The dry season starts at the end of October to early March of the following year. Average annual rain fall recorded is $1000 \mathrm{~mm}$ to $1500 \mathrm{~mm}$. The rainfall type is convectional with a single regime of maximum peak, which usually occurs in August/September at a stretch (Parkman International Studies, 1997; Abaje et al., 2009).

The population of Kaduna has grown rapidly from about 14,000 in 1929 to 40,000 in 1952 to 149,000 in 1963 to an estimated 150,000 in 1965 and 500,000 in 1984. The 1991 census put the human population of Kaduna metropolis at 971,070 (NPC, 1991). Based on $2.7 \%$ growth rate, the population was estimated to have reach $1,448,129$ in 2006(NPC, 2009). By 2009, at 3.0\% growth rate, the population was estimated to have hit $1,582,409$. The population was projected to reach $1,729,142$ by 2012 . At $3.5 \%$ growth rate the population was estimated to 2,031,742 in 2017. This high growth rate can be attributed to natural increase and high rate of immigration (National Bureau of Statistics, 2012; Akpu, 2012).

\section{Methodology}

The study started with a reconnaissance survey, with the aim of familiarization with the study area. Also, this was done in order to identify all possible variables as it relates with air quality in the study area, such as identifying and having a good picture of all 
possible land uses affecting the city air quality (i.e road traffic, industrial, residential and commercial land uses).

The needed information was obtained through direct field survey, the exercise of measurements and observations of the air quality attributes was carried out. This was done by using a handheld air quality monitoring device (MSA Altair $5 x$ Gas Detector ${ }^{a}$ with accuracy level of $\pm 10 \%$ of reading) to collect data on the concentration of air pollutants $\left(\mathrm{CO}\right.$, and $\left.\mathrm{SO}_{2}\right)$, and the particulate matter meter (Chinaway CW-HAT200 Particulate Counter with an accuracy level of $+/ 5 \%$ of reading') to test the concentration of particulate matters $\left(\mathrm{PM}_{10}\right)$, it measures in $\mu \mathrm{gm}-3$. The level of each of the study air pollutants concentration were measured daily during peak (7:20 - 9:20 am for morning hours and 5:00 - 7:00 pm for evening hours) and off-peak period (12:00 noon - 2:00 pm) during the harmattan weather (cool dry season) and the wet rainy season. A structured field recording chart was design and used as a guide in the field, to assemble data on each of the study variables. 33 data collection points were selected, for equal representation of the sample sites across each of the land use. Equal allocation stratify sampling was used to allocated 8 sample sites to each of the land uses except the traffic sites which was allocate the extra one site making it to have 9 sample sites. Purposive sampling was used to select the points across the land uses (Table 1).

\section{Analytical Technique}

The AQI is a single number reporting the air quality with respect to its effects on human health (Bortnick, Coutantand and Eberly, 2002; Murena, 2004). The result is set of a rule (for example, an equation) that translates parameter values into a more parsimonious form by means of numerical manipulation. AQI is calculated by using the pollutant concentration data and the following equation (USEPA, 2006).

$$
T_{p}=\frac{I_{H i}-I_{L o}}{B P_{H i}-B P_{L o}}\left(C_{p}-B P_{L o}\right)+I_{L o}
$$

Where:

- $I_{p}=$ the index for pollutant $\mathrm{p}$

- $C_{p}=$ the rounded concentration of pollutant $\mathrm{p}$

- $B P_{H i}=$ the breakpoint that is greater than or equal to $\mathrm{Cp}$

- $B P_{L o}=$ the breakpoint that is less than or equal to $\mathrm{Cp}$

- $I_{H i}=$ the AQI value corresponding to $\mathrm{BPHi}$

- $I_{L o}=$ the AQI value corresponding to BPLo"

Table 1. Sample Collection Sites

\begin{tabular}{|l|l|c|c|c|}
\hline Location & Land Use & SID & Easting $(\mathrm{m})$ & Northing $(\mathrm{m})$ \\
\hline Refinery Junction & Traffic & T01 & 335255.28977 & 1154676.87638 \\
\hline Sabon Tasha & Traffic & T02 & 330932.759925 & 1155614.04512 \\
\hline Abuja Junction & Traffic & T03 & 325387.082167 & 1154788.54347 \\
\hline
\end{tabular}




\begin{tabular}{|c|c|c|c|c|}
\hline Location & Land Use & SID & Easting $(\mathrm{m})$ & Northing (m) \\
\hline Peugeot Junction & Traffic & T04 & 327503.753067 & 1156349.58826 \\
\hline Station Roundabout & Traffic & T05 & 327059.252178 & 1160482.38819 \\
\hline Leventis Roundabout & Traffic & T06 & 328302.313731 & 1163492.95038 \\
\hline Kawo Fly Over & Traffic & T07 & 330127.942382 & 1170533.52696 \\
\hline Mando Roundabout & Traffic & T08 & 328614.522689 & 1170464.73515 \\
\hline Bakin Ruwa Junction & Traffic & T09 & 324810.289347 & 1162710.18431 \\
\hline Refinery & Industrial & 101 & 334704.81105 & 1152686.90286 \\
\hline Indomie Noodles & Industrial & 102 & 335906.021796 & 1154374.9479 \\
\hline Coca Cola & Industrial & 103 & 326807.088588 & 1155671.83216 \\
\hline Brewery & Industrial & 104 & 326614.471536 & 1158596.013 \\
\hline AdkadRoverocom Ventures & Industrial & 105 & 323778.13253 & 1158670.09649 \\
\hline Yuguda Plastic \& Paper Ind & Industrial & 106 & 329709.39717 & 1170195.01676 \\
\hline Global Care Industries & Industrial & 107 & 328738.374392 & 1169800.46931 \\
\hline Doka Printing & Industrial & 108 & 328021.352127 & 1161593.92456 \\
\hline Sabo Market & Commercial & $\mathrm{C} 01$ & 331386.858857 & 1155656.23935 \\
\hline Barnawa Market & Commercial & $\mathrm{CO} 2$ & 328481.728048 & 1159246.64237 \\
\hline Television Market & Commercial & $\mathrm{CO3}$ & 328209.20667 & 1155563.635 \\
\hline Kakuri Market & Commercial & $\mathrm{CO} 4$ & 325743.285074 & 1157587.70155 \\
\hline Central Market & Commercial & $\mathrm{CO5}$ & 328256.831765 & 1163059.29582 \\
\hline Kabala Market & Commercial & $\mathrm{CO6}$ & 329738.501395 & 1161228.3755 \\
\hline Kawo Market & Commercial & $\mathrm{CO} 7$ & 330339.000929 & 1169846.1894 \\
\hline KasuwanBachi & Commercial & $\mathrm{CO8}$ & 326129.048343 & 1162870.40411 \\
\hline AngwanShanu & Residential & R01 & 329244.770974 & 1166390.85115 \\
\hline Sabo & Residential & $\mathrm{R} 02$ & 331093.894672 & 1155875.23012 \\
\hline Tudun Wada & Residential & R03 & 326542.205569 & 1162149.04267 \\
\hline Rigasa & Residential & R04 & 324322.241129 & 1164236.92685 \\
\hline Barnawa GRA & Residential & R05 & 327741.087967 & 1159014.6764 \\
\hline UngwanRimi GRA & Residential & R06 & 330523.981047 & 1163931.7029 \\
\hline Malali GRA & Residential & R07 & 332410.993141 & 1166036.73211 \\
\hline KurminMashi GRA & Residential & R08 & 326516.805518 & 1165766.0099 \\
\hline
\end{tabular}

Also, the indexes for each of the pollutants can simply be derived using the mathematical formula in Eq. (2):

$$
A Q I_{\text {pollutant }}=\frac{\text { pollutant data reading }}{\text { standard }} \cdot 100 \quad \text { (2)USEPA (2003). }
$$

The AQI runs on a yardstick of 0 to 500. The higher the AQI value, the greater the level of air pollution and the greater the health concern. For example, an AQI value of 50 represents good air quality with little potential to affect public health, while an AQI 
value over 300 represents hazardous air quality (USEPA, 2003). A summary of the interpretation of the AQI values according to USEPA (2003) are as presented in Table 2.

Table 2: Interpretations of the AQI Values Classification

\begin{tabular}{|c|l|c|c|c|c|}
\hline Index Values & AQI Category & $\begin{array}{c}\mathrm{AQI} \\
\text { Rating }\end{array}$ & $\mathrm{PM}_{10}\left(\mu \mathrm{g} / \mathrm{m}^{3}\right)$ & $\mathrm{CO}(\mathrm{ppm})$ & $\mathrm{SO}_{2}(\mathrm{ppm})$ \\
\hline $0-50$ & Good & $\mathrm{A}$ & $0-54$ & $0-4.4$ & $0-0.035$ \\
$51-100$ & Moderate & $\mathrm{B}$ & $55-154$ & $4.5-9.4$ & $0.036-0.075$ \\
$101-150$ & Unhealthy for sensitive groups & $\mathrm{C}$ & $155-254$ & $9.5-12.4$ & $0.076-0.185$ \\
$151-200$ & Unhealthy & $\mathrm{D}$ & $255-354$ & $12.5-15.4$ & $0.186-0.304$ \\
$201-300$ & Very unhealthy & $\mathrm{E}$ & $355-424$ & $15.5-30.4$ & $0.305-0.604$ \\
$301-500$ & Hazardous & $\mathrm{F}$ & $425-504$ & $30.5-50.4$ & $0.605-1.004$ \\
\hline
\end{tabular}

Source: USEPA (2003)

\section{Data Processing}

The study involved integrating the air pollutants data from field measurements (AQI data) into digital map layers, this was to aid shows the spatial distribution of the pollutants AQI in Kaduna metropolis. Locational coordinates of Longitude (x-coordinate), Latitude (y-coordinate) and elevation above mean sea level of the sampling sites determined using Garmin Global Positioning System (GPS) device. Also, the AQI result stored in Microsoft excel software using the CSV (comma delimited) format. The excel spread sheet was imported in to ArcGIS 10.6 environment and plot as a point map and also converted in to shapefile for analysis. Attribute data were then assigned to spatial objects and the system become ready for spatio-temporal analysis and management. The findings of the study were presented using maps and descriptive statistics.

\section{RESULT AND DISCUSSION}

This Section analyzed the AQI values based on WHO, USEPA and NESREA ambient standard for each of the air pollutants during the raining season and dry harmattan weather.

\section{Raining Season AQI}

This section discusses the result of $\mathrm{AQI}$ of $\mathrm{CO}, \mathrm{SO} 2$ and $\mathrm{PM}$ during the raining season, using WHO, USEPA and NESREA standard.

Carbon Monoxide: Inhalation of CO reduces the amount of oxygen in the bloodstream, and high concentrations can lead to headaches, dizziness, unconsciousness and death (USEPA 2014; Delay and Zanetti, 2007). The result of finding is presented in Table 2 and Figure 2 to 7 .

The finding reveals that the AQI for $\mathrm{CO}$ in Kaduna Metropolis ranges from good to hazardous, this agree with the findings of Saniei et al. (2016) on Air quality classifica- 




Figure 2. Spatial Analysis of CO AQI for Wet Season Based on WHO/USEPA Standard Source: Fieldwork (2019)

tion and its temporal trend in Tehran, Iran, and Attah (2015). The finding disagrees with the submission of Chizoruo et al. (2017) on the ambient air quality assessment of Orlu, Southeastern, Nigeria, and Adedeji et al. (2016) whose finding shows only unhealthy and very unhealthy AQI. The result reveals that $21.21 \%$ of the sample sites air quality base on USEPA and WHO standard are good, in as the NESREA standard shows that $33.33 \%$ are good, the good sites are fairly distributed in both the north and southern part of the study area (Table 2). Similarly, NESREA standard shows that $24.24 \%$ of the sites are moderate, while WHO and USEPA standard shows that only $9 \%$ of the sites are moderate, the moderate sites are randomly distributed in both the north and southern part of the study area (Table 3). Similarly, NESREA standard reveals that $18.18 \%$ of the sample sites are unhealthy to sensitive group, whereas WHO and USEPA standard reveals $12.12 \%$, in both the northern and the southern part of the metropolis have sites that are unhealthy for sensitive group randomly distributed. 


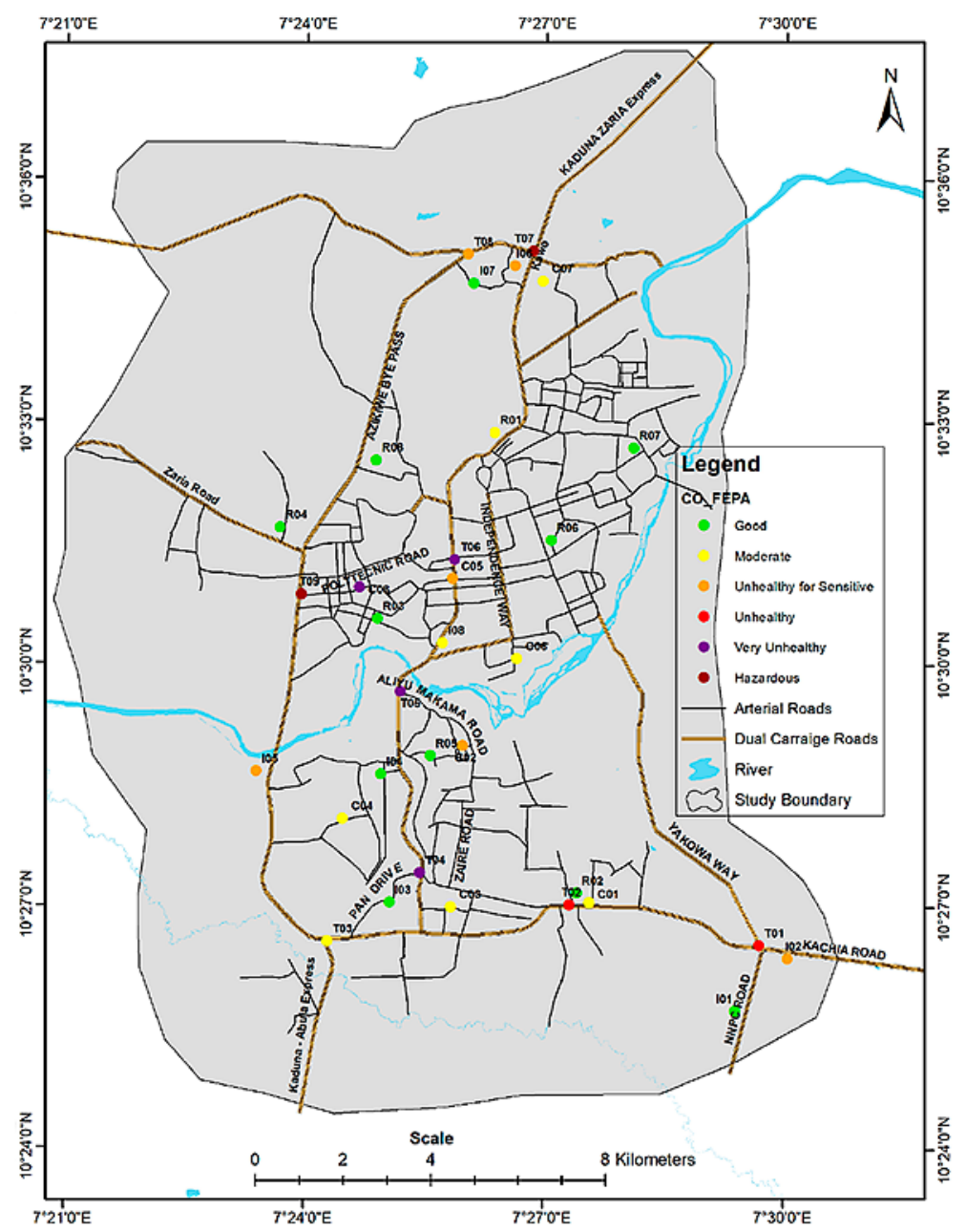

Figure 3: Spatial Distribution of CO AQI for Wet Season Based on NESREA Standard Source: Fieldwork (2019)

The result of USEPA/WHO standard shows that $15.15 \%$ of the sites are unhealthy, whereas, NESREA standard shows a decrease $6 \%$ the unhealthy sites where found in both the north and south. USEPA and WHO standard also shows that $18.18 \%$ of the sites are very unhealthy, whereas NESREA standard shows a decrease (12.12\%), most of the very unhealthy sites are found in the northern part of the metropolis (Table 3). Equally USEPA standard reveals $24.24 \%$ of the sites to be hazardous, whereas NESREA standard reveals only $6 \%$, the hazardous sites are found more in the northern part of the metropolis than the southern part. This implies that most of the sites are unsafe for human health.

Thus, according to USEPA (2014) "people with cardiovascular disease, such as coronary artery disease, are most at risk. They may experience chest pain and other cardiovascular symptoms if they are exposed to carbon monoxide, particularly while exercising". People with marginal or compromised cardiovascular and respiratory systems (for 
example, individuals with congestive heart failure, cerebrovascular disease, anemia, or chronic obstructive lung disease), and possibly young infants and fetuses, also may be at greater risk from carbon monoxide pollution.

The result further reveals that the traffic sites have about $78 \%$ of its sites as hazardous base on USEPA standard, whereas NESREA standard reveals 22\%, with Abuja junction and Mando roundabout having moderate and unhealthy to sensitive group AQI respectively, all other sites are unhealthy base on NESREA standard. The NESREA standards shows that the industrial sites $\mathrm{CO}$ emission is satisfactory with only $37.5 \%$ of the sites unhealthy for sensitive groups, other sites have good and moderate air quality, whereas USEPA standard reveals that $12.5 \%$ and $37.5 \%$ of the sites are unhealthy and very unhealthy respectively, distributed in both the north and southern part of the study area. Majority (62.5\%) of the commercial sites AQI base on NESREA standard is moderate, $25 \%$ and $12.5 \%$ unhealthy for sensitive groups and very unhealthy respectively, whereas USEPA standard shows that $62.5 \%$ of the sites differs from unhealthy, very unhealthy to hazardous, with $37.5 \%$ of the sites unhealthy to sensitive groups. The AQI for residential areas is satisfactory for both NESREA and USEPA standards, except for Ungwan Shanu site which is unhealthy base on USEPA standard.

$\mathrm{SO}_{2}$ : $\mathrm{SO} 2$ can cause coughing, mucus secretion, and other conditions such as asthma and chronic bronchitis (QEPA, 2001). Some studies show a consistent effect of $\mathrm{SO}_{2}$ pollution on cardiorespiratory mortality and acid rain (Fischer, Hoek, Brunekreef, Verhoeff and Van-Wijnen, 2003; Venners, et al., 2003; Wong, Tam, Yu, and Wong, 2002; Powe and Willis, 2004; Wai and Steven, 2007).

Table 2: Air Quality Index Percentage Summary for the Raining Season

\begin{tabular}{|c|c|c|c|c|c|c|c|c|}
\hline & \multicolumn{2}{|c|}{$\mathrm{CO}$} & \multicolumn{3}{|c|}{$\mathrm{SO}_{2}$} & \multicolumn{3}{|c|}{$\mathrm{PM}_{10}$} \\
\hline & $\begin{array}{l}\text { WHO/ } \\
\text { USEPA \% }\end{array}$ & $\begin{array}{c}\text { NESREA } \\
\%\end{array}$ & $\begin{array}{c}\text { WHO } \\
\%\end{array}$ & $\begin{array}{c}\text { USEPA } \\
\%\end{array}$ & $\begin{array}{c}\text { NESREA } \\
\%\end{array}$ & $\begin{array}{c}\text { WHO } \\
\%\end{array}$ & $\begin{array}{c}\text { USEPA } \\
\%\end{array}$ & $\begin{array}{c}\text { NESREA } \\
\%\end{array}$ \\
\hline Good & 21.21 & 33.33 & 9.09 & 24.24 & 24.24 & 0 & 15.15 & 24.24 \\
\hline Moderate & 9.09 & 24.24 & 0 & 24.24 & 30.30 & 6.06 & 9.09 & 9.09 \\
\hline Sensitive & 12.12 & 18.18 & 3.03 & 9.09 & 3.03 & 12.12 & 9.09 & 39.39 \\
\hline Unhealthy & 15.15 & 6.06 & 3.03 & 3.03 & 24.24 & 3.03 & 27.27 & 9.09 \\
\hline Very Unhealthy & 18.18 & 12.12 & 3.03 & 30.30 & 12.12 & 3.03 & 21.21 & 18.18 \\
\hline Hazardous & 24.24 & 6.06 & 81.82 & 9.09 & 6.06 & 75.76 & 18.18 & 0 \\
\hline \multicolumn{9}{|l|}{ Traffic Sites } \\
\hline Good & 0 & 0 & 0 & 11.11 & 11.11 & 0 & 0 & 0 \\
\hline Moderate & 0 & 11.11 & 0 & 11.11 & 11.11 & 0 & 0 & 11.11 \\
\hline Sensitive & 0 & 11.11 & 0 & 0 & & 0 & 11.11 & 55.56 \\
\hline Unhealthy & 11.11 & 22.22 & 0 & 0 & 55.56 & 0 & 44.44 & 0 \\
\hline Very Unhealthy & 11.11 & 33.33 & 0 & 66.67 & 11.11 & 0 & 11.11 & 33.33 \\
\hline Hazardous & 77.78 & 22.22 & 100 & 11.11 & 11.11 & 100 & 33.33 & 0 \\
\hline \multicolumn{9}{|l|}{ Industrial Sites } \\
\hline Good & 37.5 & 50 & 12.50 & 37.5 & 37.5 & 0 & 12.5 & 37.5 \\
\hline Moderate & 12.5 & 12.5 & 0 & 12.5 & 25 & 12.5 & 25 & 12.5 \\
\hline
\end{tabular}




\begin{tabular}{|c|c|c|c|c|c|c|c|c|}
\hline & \multicolumn{2}{|c|}{$\mathrm{CO}$} & \multicolumn{3}{|c|}{$\mathrm{SO}_{2}$} & \multicolumn{3}{|c|}{$\mathrm{PM}_{10}$} \\
\hline & $\begin{array}{l}\text { WHO/ } \\
\text { USEPA \% }\end{array}$ & $\begin{array}{c}\text { NESREA } \\
\%\end{array}$ & $\begin{array}{c}\text { WHO } \\
\%\end{array}$ & $\begin{array}{c}\text { USEPA } \\
\%\end{array}$ & $\begin{array}{c}\text { NESREA } \\
\%\end{array}$ & $\begin{array}{c}\text { WHO } \\
\%\end{array}$ & $\begin{array}{c}\text { USEPA } \\
\%\end{array}$ & $\begin{array}{c}\text { NESREA } \\
\%\end{array}$ \\
\hline Sensitive & 0 & 37.5 & 0 & 12.5 & & 12.5 & 2.5 & 37.5 \\
\hline Unhealthy & 12.5 & 0 & 12.50 & & 12.5 & 0 & 0 & 12.5 \\
\hline Very Unhealthy & 37.5 & 0 & 0 & 25 & 25 & 12.5 & 50 & 0 \\
\hline Hazardous & 0 & 0 & 75.00 & 12.5 & 0 & 62.50 & 0 & 0 \\
\hline \multicolumn{9}{|c|}{ Commercial Sites } \\
\hline Good & 0 & 0 & 0 & 0 & 0 & 0 & 0 & 0 \\
\hline Moderate & 0 & 62.5 & 0 & 50 & 50 & 0 & 12.5 & 12.5 \\
\hline Sensitive & 37.5 & 25 & 0 & 12.5 & 12.5 & 0 & & 50 \\
\hline Unhealthy & 25 & 0 & 0 & 0 & 12.5 & 0 & 50 & 12.5 \\
\hline Very Unhealthy & 25 & 12.5 & 0 & 25 & 12.5 & 0 & 12.5 & 0 \\
\hline Hazardous & 12.5 & 0 & 100 & 12.5 & 12.5 & 100 & 25 & 25 \\
\hline \multicolumn{9}{|l|}{ Residential Sites } \\
\hline Good & 50 & 87.5 & 37.50 & 50 & 50 & 0 & 50 & 62.5 \\
\hline Moderate & 25 & 12.5 & 0 & 25 & 37.5 & 12.5 & 12.5 & \\
\hline Sensitive & 12.5 & & 12.50 & 12.5 & & 37.5 & 12.5 & 12.5 \\
\hline Unhealthy & 12.5 & & 0 & 12.5 & 12.5 & 12.5 & & 12.5 \\
\hline Very Unhealthy & 0 & 0 & 0 & 0 & 0 & 0 & 12.5 & 12.5 \\
\hline Hazardous & 0 & 0 & 50.00 & 0 & 0 & 37.5 & 12.5 & 0 \\
\hline
\end{tabular}

Source: Fieldwork (2019)

Table 3: Spatial Analysis of Air Quality Index during the Raining Season

\begin{tabular}{|l|c|c|c|c|c|c|c|c|}
\hline \multirow{2}{*}{} & \multicolumn{9}{|c|}{ CO } & \multicolumn{7}{c|}{ SO $_{2}$} & \multicolumn{3}{c|}{ PM $_{10}$} \\
\cline { 2 - 10 } & $\begin{array}{l}\text { WHO/ } \\
\text { USEPA } \%\end{array}$ & $\begin{array}{c}\text { NESREA } \\
\%\end{array}$ & $\begin{array}{c}\text { WHO } \\
\%\end{array}$ & $\begin{array}{c}\text { USEPA } \\
\%\end{array}$ & $\begin{array}{c}\text { NESREA } \\
\%\end{array}$ & $\begin{array}{c}\text { WHO } \\
\%\end{array}$ & $\begin{array}{c}\text { USEPA } \\
\%\end{array}$ & $\begin{array}{c}\text { NESREA } \\
\%\end{array}$ \\
\hline Northern Part \\
\hline Good & 23.53 & 35.29 & 17.65 & 23.53 & 23.53 & 0 & 17.65 & 17.65 \\
\hline Moderate & 5.88 & 23.53 & 0 & 17.65 & 29.41 & 0 & 0 & 11.76 \\
\hline Sensitive & 11.76 & 17.65 & 0 & 17.65 & 5.88 & 17.65 & 11.76 & 17.65 \\
\hline Unhealthy & 17.65 & 0 & 0 & 5.88 & 11.76 & 0 & 11.76 & 17.65 \\
\hline Very Unhealthy & 11.76 & 11.76 & 0 & 23.53 & 23.53 & 0 & 23.53 & 35.29 \\
\hline Hazardous & 29.41 & 11.76 & 82.35 & 11.76 & 11.76 & 82.35 & 35.29 & 0 \\
\hline Southern Part & & & & & & & \\
\hline Good & 18.75 & 31.25 & 0 & 25.00 & 25.00 & 0 & 12.50 & 31.25 \\
\hline Moderate & 12.50 & 25.00 & 0 & 31.25 & 31.25 & 12.5 & 18.75 & 6.25 \\
\hline Sensitive & 12.50 & 18.75 & 6.25 & 0 & 0 & 6.26 & 6.25 & 62.50 \\
\hline Unhealthy & 12.50 & 12.50 & 6.25 & 0 & 31.25 & 6.26 & 43.75 & 0 \\
\hline Very Unhealthy & 25.00 & 6.25 & 6.25 & 37.50 & 6.25 & 6.26 & 18.75 & 0 \\
\hline Hazardous & 18.75 & 0 & 81.25 & 6.25 & 0 & 68.75 & 0 & 0 \\
\hline
\end{tabular}

Source: Fieldwork (2019) 
The findings from Figures 4 and 5 reveals that the AQI for SO2 in Kaduna Metropolis ranges from good to hazardous, this result disagree with the submission of Attah (2015) who reported that the AQI of SO2 is good in all the traffic sites in Kaduna metropolis, and also the submission of Chizoruo et al. (2017) who reported the AQI of SO2 to be only very unhealthy and hazardous. However, it agrees with the findings of Adedeji et al. (2016). The findings further reveal that $24.24 \%$ of the sites AQI is good base on both USEPA and NESREA standard, it equally shows that the good AQI is fairly well distributed in both the northern and southern part of the metropolis. It also reveals that $24.24 \%$ of the sites AQI is moderate base on USEPA standard and $30.30 \%$ base on NESREA, randomly distributed in both the north and southern part of the metropolis.

Similarly, USEPA standard shows that $9 \%$ of the sites AQI is unhealthy for sensitive group, whereas NESREA standard shows only $3 \%$. Also, NESREA standard shows

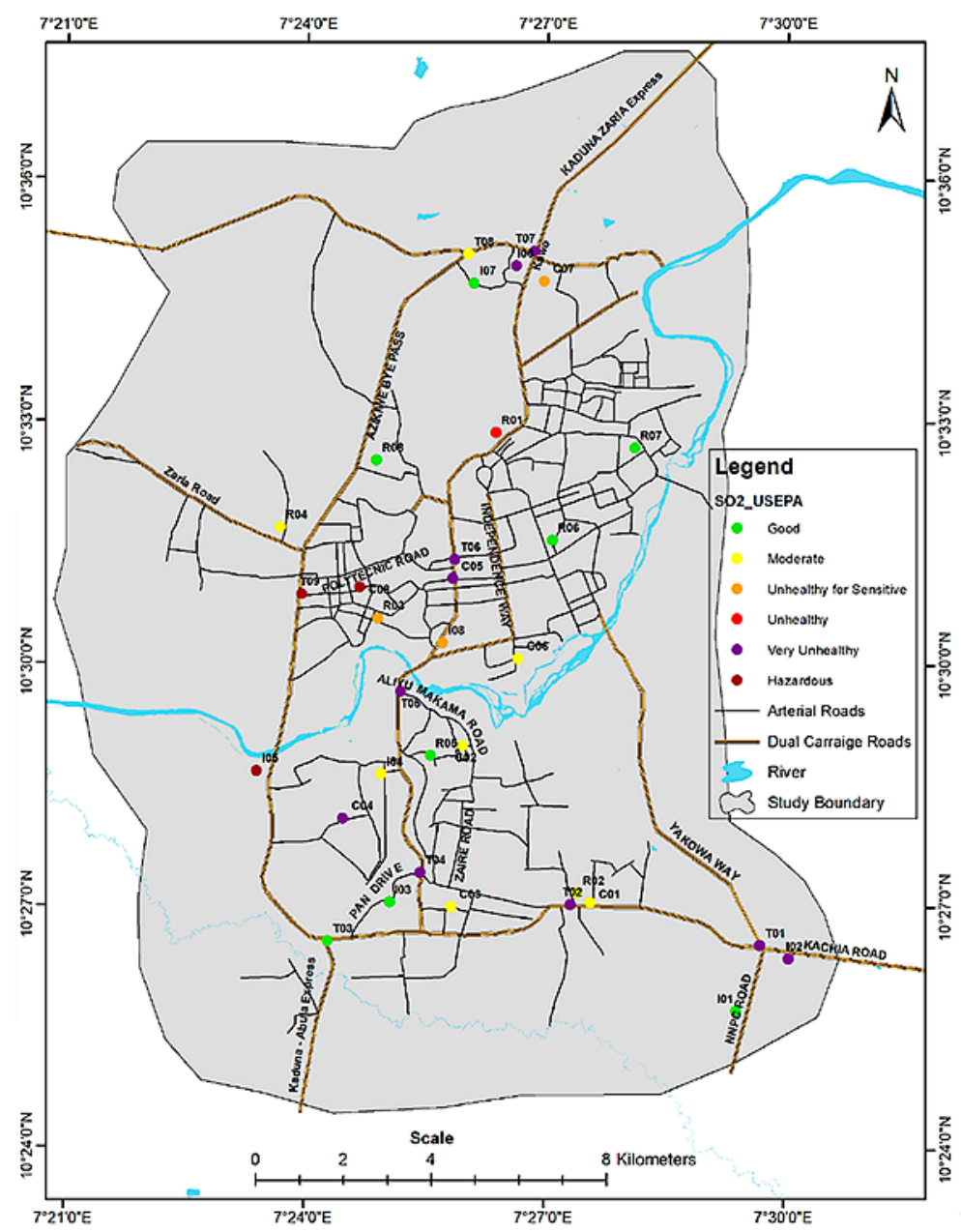

Figure 4. Spatial Analysis of $\mathrm{SO}_{2} \mathrm{AQI}$ for Wet Season Based on USEPA Standard Source: Fieldwork (2019) 
that $24.24 \%$ of the sites air quality is unhealthy, whereas USEPA standard shows only $3 \%$ to be unhealthy, the unhealthy sites are more in the southern part of the study area than the northern part. $30.3 \%$ of the sites are very unhealthy base on USEPA standard, while NESREA standard shows $12.12 \%$, it equally shows more of the very unhealthy sites in the northern part contrary to the unhealthy AQI found more in the southern part of the metropolis. Over $80 \%$ of the sites are hazardous base on WHO standard, while only $9 \%$ and $6 \%$ of the sites are hazardous base on USEPA and NESREA standard respectively, found mostly in the northern part of the metropolis as shown in Figures 4 and 5 .

Consequently, according to USEPA (2014) "people with asthma who are physically active outdoors are most likely to experience the health effects of sulfur dioxide. The main effect, even with very brief exposure (minutes), is a narrowing of the airways

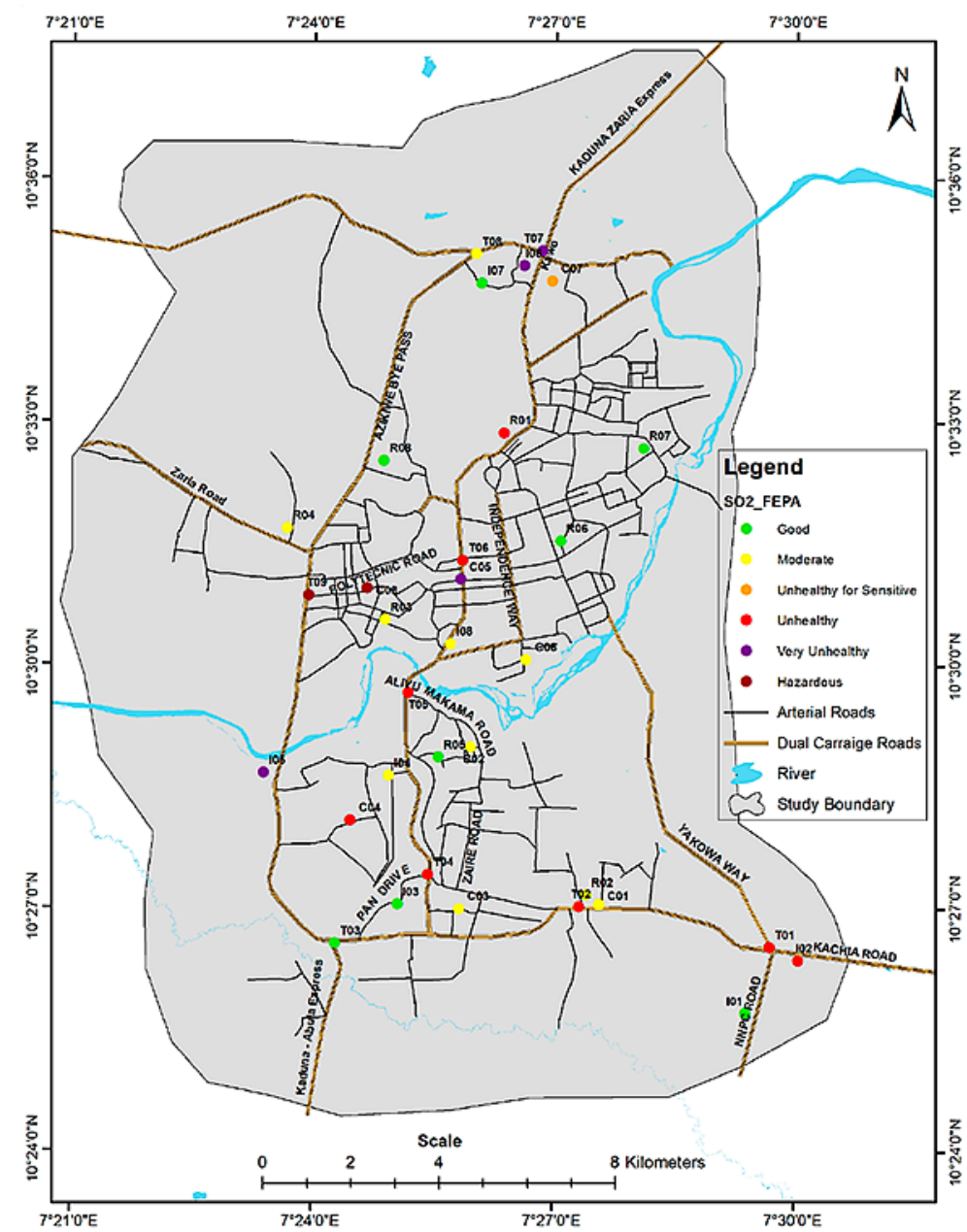

Figure 5. Spatial Analysis of $\mathrm{SO}_{2} \mathrm{AQI}$ for Wet Season Based on NESREA Standard Source: Fieldwork (2019) 
(called bronchoconstriction). This may be accompanied by wheezing, chest tightness, and shortness of breath, which may require use of medication that opens the airways". Symptoms increase as sulfur dioxide levels or breathing rate increases. At very high levels, sulfur dioxide may cause wheezing, chest tightness, and shortness of breath even in healthy people who do not have asthma.

Further probe reveals that the traffic sites have about $78 \%$ of its sites as very unhealthy and hazardous base on USEPA standard, NESREA standard also shows that about $78 \%$ of the sites differs from unhealthy, very unhealthy and hazardous, with only $22.22 \%$ of its sites AQI as satisfactory. The industrial sites reveal that $50 \%$ and $62.5 \%$ of the sites AQI as safe base on USEPA and NESREA standards respectively, and both USEPA and NESREA standards reveals that $25 \%$ of the sites are very unhealthy, also $12.5 \%$ of the sites are hazardous base on USEPA standard. The commercial sites reveal that $50 \%$ of the sites AQI is moderate base on both USEPA and NESREA standard and also $12.5 \%$ are unhealthy to sensitive group, $25 \%$ and $12.5 \%$ of the sites are very unhealthy and hazardous respectively base on USEPA standard, whereas NESREA standard reveals $12.5 \%$ for both very unhealthy and hazardous AQI. The AQI for residential area is satisfactory base on both USEPA and NESREA standard, except for Ungwan Shanu area which is unhealthy.

$\mathbf{P M}_{10}$ : The findings from Table 3, Figures 6 and 7 reveals that the AQI for $\mathrm{PM}_{10}$ in Kaduna Metropolis ranges from good to hazardous, this agree with the submission of Saniei et al. (2016) and Chizoruo (2017), who's finding equally shows an AQI which ranges from good to hazardous. The analysis base on NESREA standard reveals that $24.24 \%$ of the sites are Good, whereas USEPA standard shows a decrease $15.15 \%$ of the sites, which are randomly distributed in both the northern and southern part of the metropolis. 9\% of the sites AQI is moderate for both the USEPA and NESREA standard, which are found in the southern part of the metropolis for the USEPA standard and more in the northern part in Figure 4b. Also, NESREA standard shows that $39.39 \%$ of the sites are unhealthy to sensitive, whereas USEPA standard shows only $9 \%$, the spatial analysis reveals that most of the sites are unhealthy for sensitive groups are found in the southern part of the state. $27.27 \%$ of the sites are unhealthy base on USEPA standard, whereas a decrease is observed for the NESREA standard 9.09\%, which are distributed in both the northern and southern part of the metropolis, though more are found in the southern part of the metropolis (Figure 6).

Similarly, USEPA standard reveals $21.21 \%$ of the sites to be very unhealthy and NESREA standard shows that $18.18 \%$ of the locations are very unhealthy, the spatial analysis shows that most of the very unhealthy sites are in the northern part of the metropolis as shown in Figure 7. USEPA standard also reveals that $18.18 \%$ of the sites are hazardous while none of the sites is hazardous base on NESREA standard, equally the hazardous sites are only found in the northern part of the metropolis. whereas the WHO standard shows that over $75 \%$ of the sites are hazardous, spatially distributed in both the northern and southern part of the metropolis as shown in Table 4. Thus, may cause people with heart disease to experience chest pain, palpitations, shortness of breath, and fatigue. people with existing lung disease may not be able to breathe as deeply or vigorously as they normally would. They may experience symptoms such as coughing and shortness 


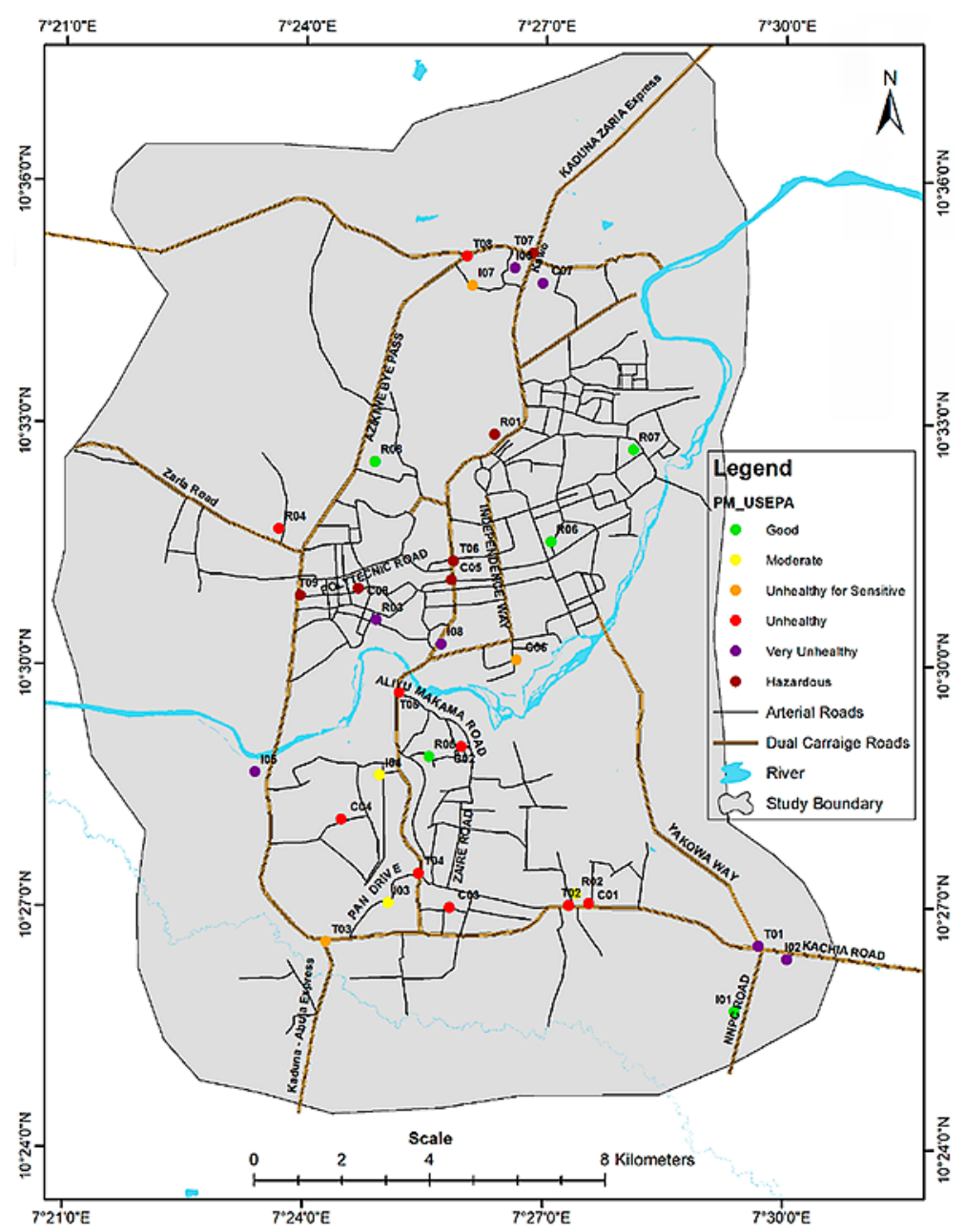

Figure 6. Spatial Analysis of PM10 AQI for Wet Season Base on USEPA Standard Source: Fieldwork (2019)

of breath. Healthy people also may experience these effects, although they are unlikely to experience more serious effects.

Additional examination of the findings reveals that the traffic sites has about $89 \%$ of its sites AQI ranging from unhealthy to hazardous base on USEPA standard, whereas NESREA standard shows $33.33 \%$ of the sites to be very unhealthy, majority (56\%) of the sites are unhealthy for sensitive group base on NESREA standard. The industrial sites finding reveals that $50 \%$ of the sites are very unhealthy base on USEPA standard, whereas NESREA standard reveals only $12.5 \%$ of the sites to be unhealthy, and $50 \%$ of the sites AQI are satisfactory base on NESREA standard, where, USEPA standard shows 37.5\%. likewise, 37.5\% of the sites are unhealthy to sensitive groups base on NESREA standard. This also concur with the submission of Notardonato, Manigrasso, Pierno, Settimo, Protano, Vitali, ... and Avino, P. (2019) that particular matter emission are mostly as result of fossil fuel emission. 


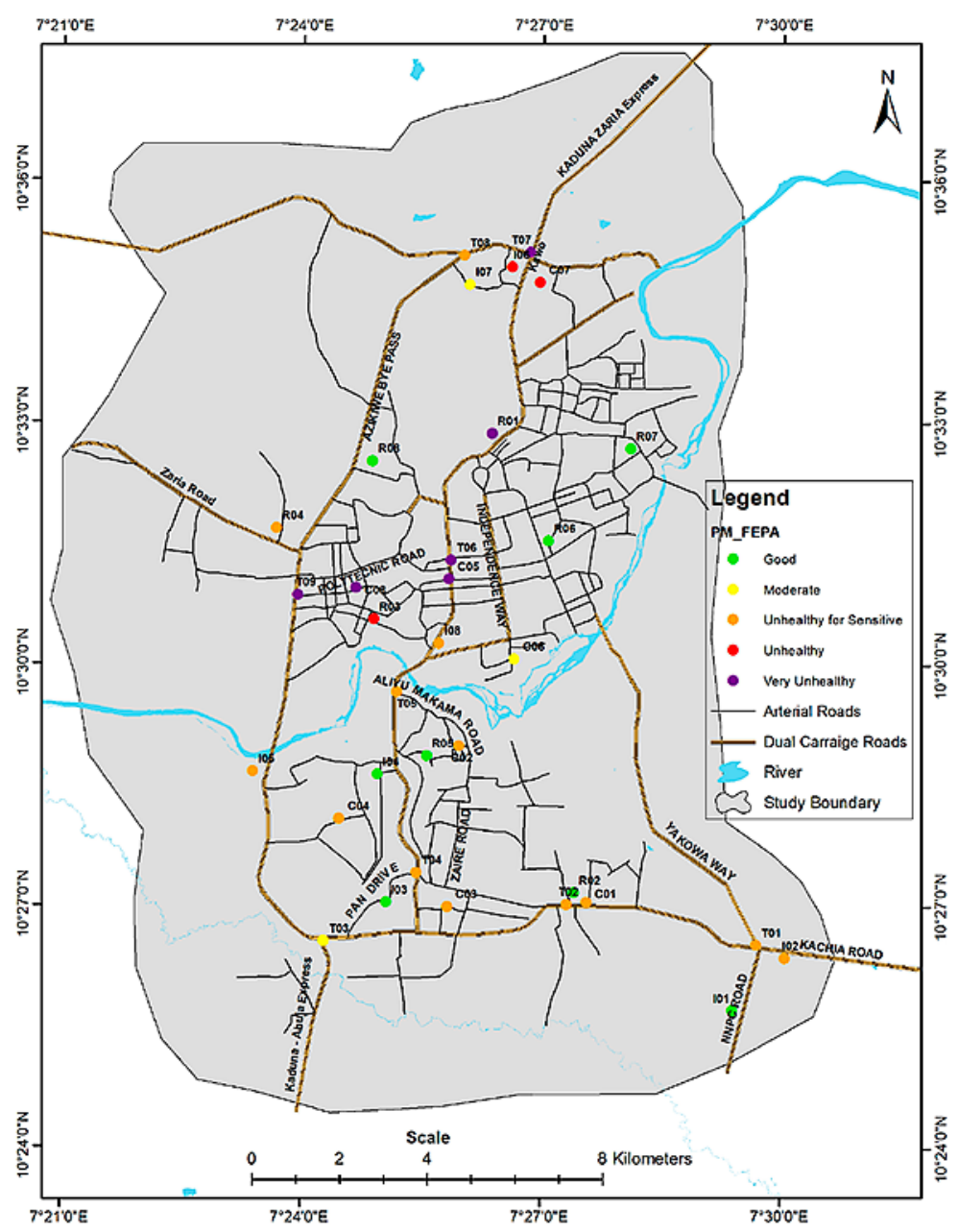

Figure 7. Spatial Analysis of PM10 AQI for Wet Season Base on NESREA Standard Source: Fieldwork (2019)

A probe of the commercial sites AQI reveals that $50 \%$ and $25 \%$ of the sites are unhealthy and hazardous respectively base on USEPA standard, whereas NESREA standard reveals that $50 \%$ and $25 \%$ of the sites are unhealthy for sensitive groups and hazardous respectively, both USEPA and NESREA standard reveals 12.5\% of the sites AQI to be moderate. The residential sites further probes reveal that $62.5 \%$ of the sites AQI are satisfactory base on both standards, similarly $12.5 \%$ of the sites are unhealthy for sensitive groups and another $12.5 \%$ very unhealthy base on both USEPA and NESREA standard. 


\section{Harmattan Weather AQI}

This section confers the $\mathrm{AQI}$ of $\mathrm{CO}, \mathrm{SO}_{2}$ and $\mathrm{PM}$ during the Harmattan Weather, using WHO, USEPA and NESREA standard. The findings are presented in Figures 8 to 13 and Table 4 and 5.

CO: The finding reveals that the AQI for CO in Kaduna Metropolis during the harmattan weather ranges from good to hazardous, this agree with the findings of Saniei et al. (2016) on Air quality classification and its temporal trend in Tehran, Iran and Attah (2015), but disagree with the submission of Chizoruo et al. (2017) on the ambient air quality assessment of Orlu, Southeastern of Nigeria, and Adedeji et al. (2016) whose finding shows only unhealthy and very unhealthy AQI. The result also reveals that $27.27 \%$ of the sample sites air quality base on WHO and USEPA standard are good, in as the NESREA standard shows that $45.45 \%$ are good, the good sites are fairly distributed in both the north and southern part of the metropolis. Similarly, NESREA standard shows that $27.27 \%$ of the sites are moderate, while USEPA/WHO standard shows that only $15.15 \%$ of the sites are moderate, the moderate sites are also randomly distributed in both the north and southern part of the study area. this implies that about $72 \%$ of the sites are safe base on NESREA standard, while USEPA and WHO standard reveals only about $42 \%$ of the sites to be safe.

Also, NESREA standard reveals that $6.06 \%$ of the sample sites are unhealthy to sensitive group, whereas USEPA and WHO standard reveals $21.21 \%$, in both the northern and the southern part of the metropolis have sites that are unhealthy for sensitive group randomly distributed. USEPA/WHO standard shows that $9.09 \%$ of the sites are unhealthy, whereas NESREA standard shows a decrease (3\%), the unhealthy sites where found in both the north and south, though NESREA standard reveal only the southern part of the metropolis. USEPA and WHO standard also shows that $3 \%$ of the sites are very unhealthy. Whereas, more of the very unhealthy sites are found in the northern part of the metropolis.

Equally WHO and USEPA standard reveals $24.24 \%$ of the sites to be hazardous, whereas NESREA standard reveals only 3\% hazardous sites are found more in the northern part of the metropolis than the southern part as shown in Tables 4 and 5. This implies that most of the sites are unsafe to human health. Consequently, according to USEPA (2014) "people with cardiovascular disease, such as coronary artery disease, are most at risk. They may experience chest pain and other cardiovascular symptoms if they are exposed to carbon monoxide, particularly while exercising". Persons with compromised respiratory and cardiovascular systems and possibly young infants and fetuses, also may be at greater risk from carbon monoxide pollution.

A further investigation reveals that About $78 \%$ of the traffic sites are hazardous base on WHO and USEPA standard, whereas NESREA standard shows only about $11 \%$ of its sites to be hazardous to humans. Likewise, $62.5 \%$ of the commercial sites are unhealthy base on WHO/USEPA standard whereas NESREA standard shows only $12.5 \%$ of the commercial sites as unhealthy, and while about $50 \%$ of the industrial sites are safe for human day to day activities. The AQI for residential areas is satisfactory for both NESREA and USEPA standards, except for Ungwan shanu area which is unhealthy base on WHO and USEPA standard. 


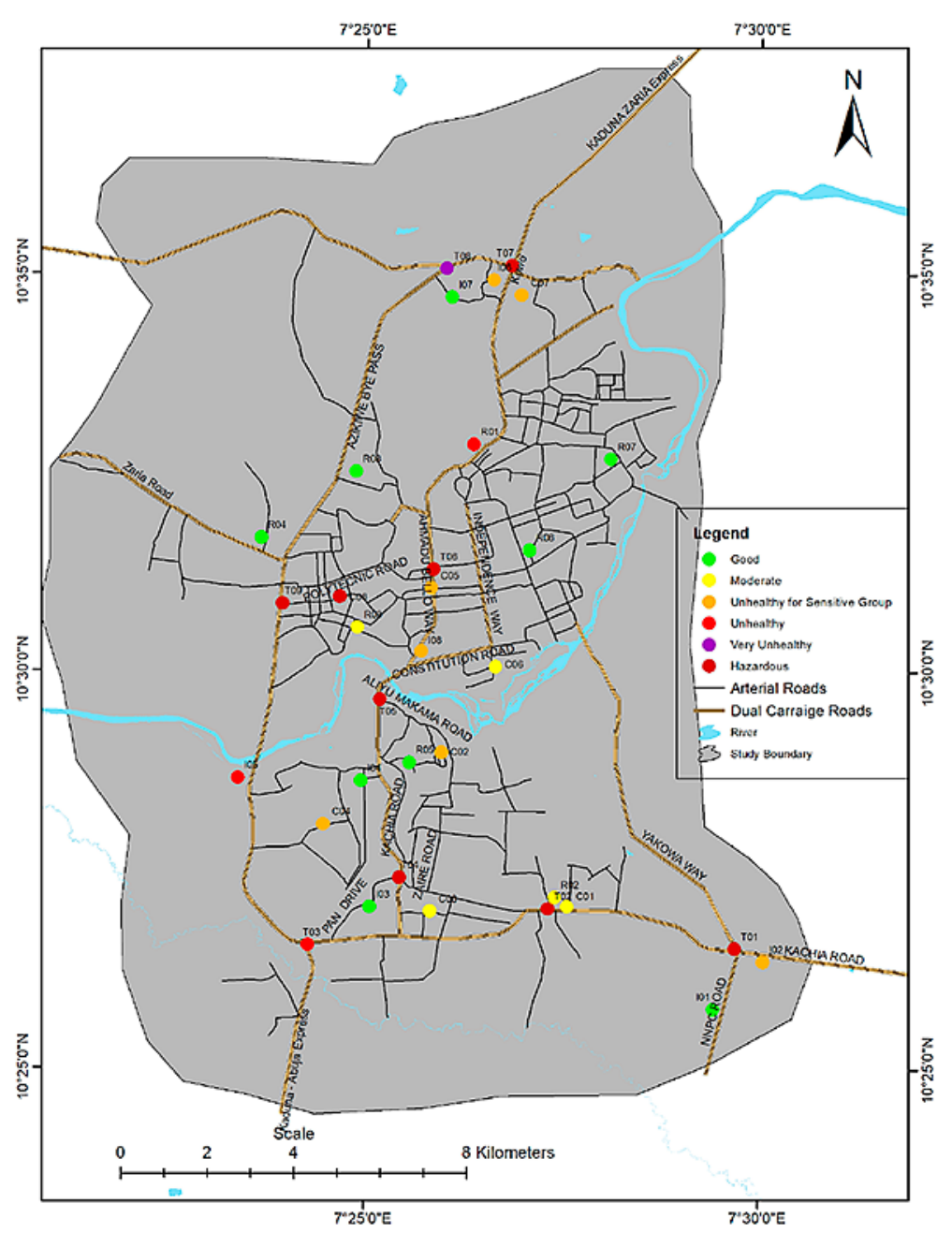

Figure 8. Spatial Analysis of CO AQI for Harmattan weather base on USEPA/WHO Standard Source: Fieldwork (2019)

$\mathrm{SO}_{2}$ : The findings from figure $6 \mathrm{a}$ and $6 \mathrm{~b}$ reveals that the $\mathrm{AQI}$ for $\mathrm{SO} 2$ during the harmattan weather in Kaduna Metropolis ranges from good to hazardous. This result disagrees with the submission of Attah (2015) who reported that the AQI of $\mathrm{SO}_{2}$ is good in all the traffic sites in Kaduna metropolis, and also the submission of Chizoruo et al. (2017) who reported the AQI of $\mathrm{SO}_{2}$ to be only very unhealthy and hazardous. However, agrees with the findings of Adedeji et al. (2016). The finding equally reveals that $27.27 \%$ of the sites AQI is good base on USEPA standard and NESREA standard shows an increase $36.36 \%$ of the locations. The result equally shows that the good AQI is fairly well distributed in both the northern and southern part of the metropolis. It also reveals that $30 \%$ of the sites AQI is moderate base on USEPA standard and 33\% base on NESREA, randomly distributed in both the north and southern part of the metropolis. This implies that $\mathrm{SO}_{2}$ emission in most of the sites (about 70\%) base on NESREA standard and 


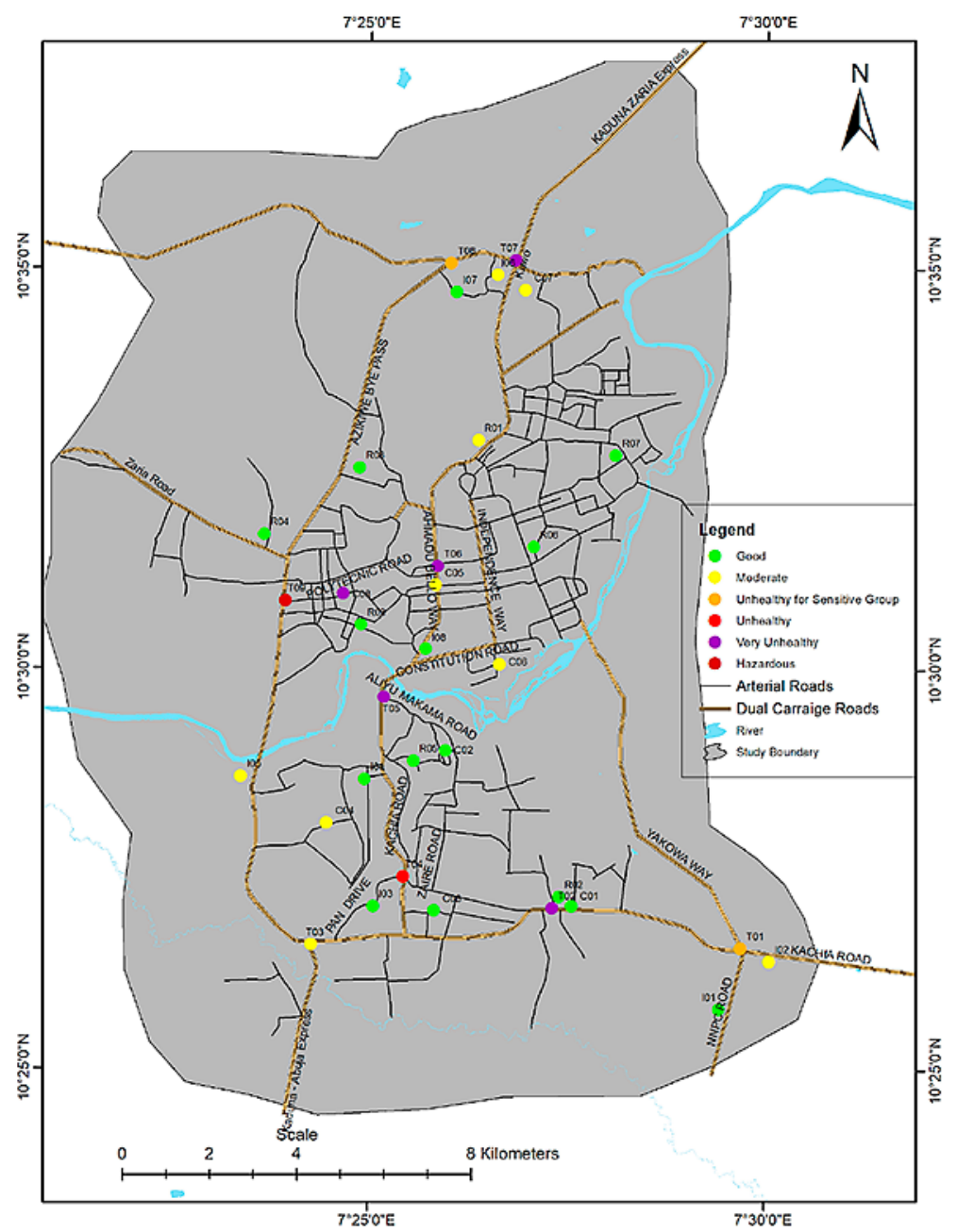

Figure 9: Spatial Distribution of CO AQI for Harmattan Weather Basedon NESREA Standard Source: Fieldwork (2019)

about $60 \%$ base USEPA standard is safe for the environment and its inhabitants. Whereas, WHO standard shows that about $85 \%$ of the sites are unsafe. 
Table 4. Air Quality Index Percentage Summary for the Dry Harmattan Weather

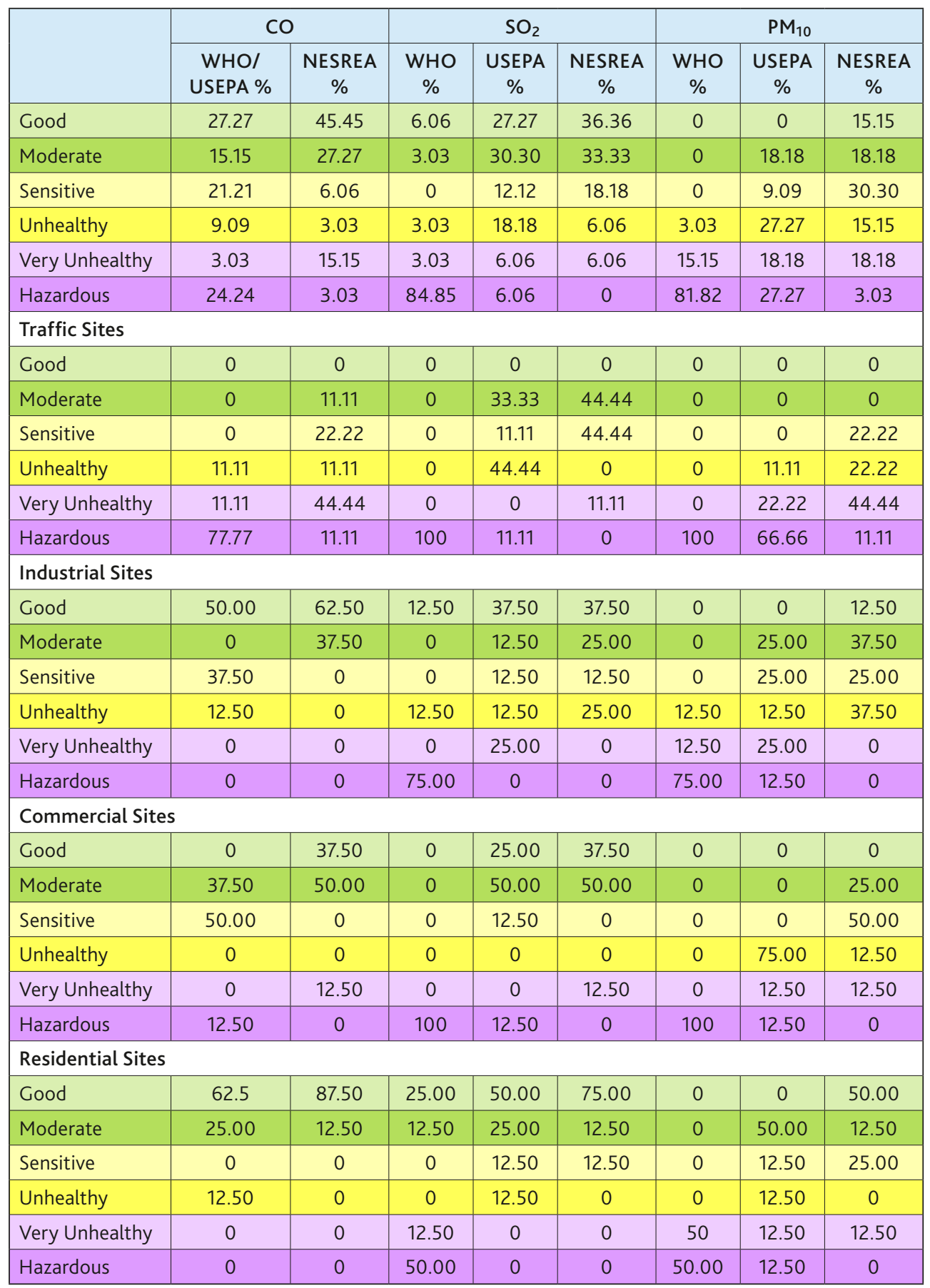

Source: Fieldwork (2019) 
Thus, according to USEPA (2014) "people with asthma who are physically active outdoors are most likely to experience the health effects of sulfur dioxide. The main effect, even with very brief exposure (minutes), is a narrowing of the airways (called bronchoconstriction)". This may be accompanied by wheezing, chest tightness, and shortness of breath, which may require use of medication that opens the airways. Symptoms increase as sulfur dioxide levels or breathing rate increases. At very high levels, sulfur dioxide may cause wheezing, chest tightness, and shortness of breath even in healthy people who do not have asthma.

Table 5: Spatial Analysis of Air Quality Index during the Dry Harmattan Weather

\begin{tabular}{|l|c|c|c|c|c|c|c|c|}
\hline \multirow{2}{*}{} & \multicolumn{9}{|c|}{ CO } & \multicolumn{7}{c|}{ SO $_{2}$} & \multicolumn{3}{c|}{ PM $_{10}$} \\
\cline { 2 - 9 } & $\begin{array}{c}\text { WHO/ } \\
\text { USEPA } \%\end{array}$ & $\begin{array}{c}\text { NESREA } \\
\%\end{array}$ & $\begin{array}{c}\text { WHO } \\
\%\end{array}$ & $\begin{array}{c}\text { USEPA } \\
\%\end{array}$ & $\begin{array}{c}\text { NESREA } \\
\%\end{array}$ & $\begin{array}{c}\text { WHO } \\
\%\end{array}$ & $\begin{array}{c}\text { USEPA } \\
\%\end{array}$ & $\begin{array}{c}\text { NESREA } \\
\%\end{array}$ \\
\hline Northern Part \\
\hline Good & 29.41 & 41.18 & 11.76 & 23.53 & 29.41 & 0 & 0 & 17.65 \\
\hline Moderate & 11.76 & 29.41 & 0 & 29.41 & 35.29 & 0 & 17.65 & 11.76 \\
\hline Sensitive & 23.53 & 5.88 & 0 & 11.76 & 17.65 & 0 & 5.88 & 35.29 \\
\hline Unhealthy & 5.88 & 0 & 0 & 17.65 & 5.88 & 0 & 29.41 & 5.88 \\
\hline Very Unhealthy & 5.88 & 17.65 & 5.88 & 5.88 & 11.76 & 17.65 & 17.65 & 23.53 \\
\hline Hazardous & 23.53 & 5.88 & 82.35 & 11.76 & 0 & 82.35 & 29.41 & 5.88 \\
\hline Southern Part & & & & & & \\
\hline Good & 25.00 & 50.00 & 6.25 & 31.25 & 43.75 & 0 & 0 & 12.50 \\
\hline Moderate & 18.75 & 25.00 & 6.26 & 31.25 & 31.25 & 0 & 18.75 & 25.00 \\
\hline Sensitive & 18.75 & 6.25 & 0 & 12.5 & 18.75 & 0 & 12.50 & 25.00 \\
\hline Unhealthy & 12.50 & 6.25 & 6.25 & 18.75 & 6.25 & 6.25 & 25.00 & 25.00 \\
\hline Very Unhealthy & 0 & 12.50 & 0 & 6.25 & 0 & 12.5 & 18.75 & 12.50 \\
\hline Hazardous & 25.00 & 0 & 81.25 & 0 & 0 & 81.25 & 25.00 & 0 \\
\hline
\end{tabular}

Source: Fieldwork (2019)

The result shows that USEPA standard have $12.12 \%$ of the sites AQI being unhealthy for sensitive group, whereas NESREA standard shows $18.18 \%$. Also, NESREA standard shows that $24.24 \%$ of the sites air quality is unhealthy, whereas USEPA standard shows only $6 \%$ to be unhealthy, the unhealthy sites are more in the southern part of the study area than the northern part. $2 \%$ of the sites are unhealthy and hazardous base on both the USEPA and NESREA standard, found mostly in the northern part of the metropolis (Figures10 and 11).

Further probe reveals that the $33 \%$ of the traffic sites are safe base on both USEPA and NESREA standard, however, WHO standard shows that all the traffic sites are unsafe. While about $45 \%$ of the traffic sites are unhealthy base on USEPA standard, whereas NESREA standard shows the same $45 \%$ of the traffic sites to be unhealthy only for sensitive group of people. Also $50 \%$ of the industrial sites are unhealthy base on USEPA standard whereas, NESREA standard shows only about $25 \%$ of the sites to be unhealthy. 


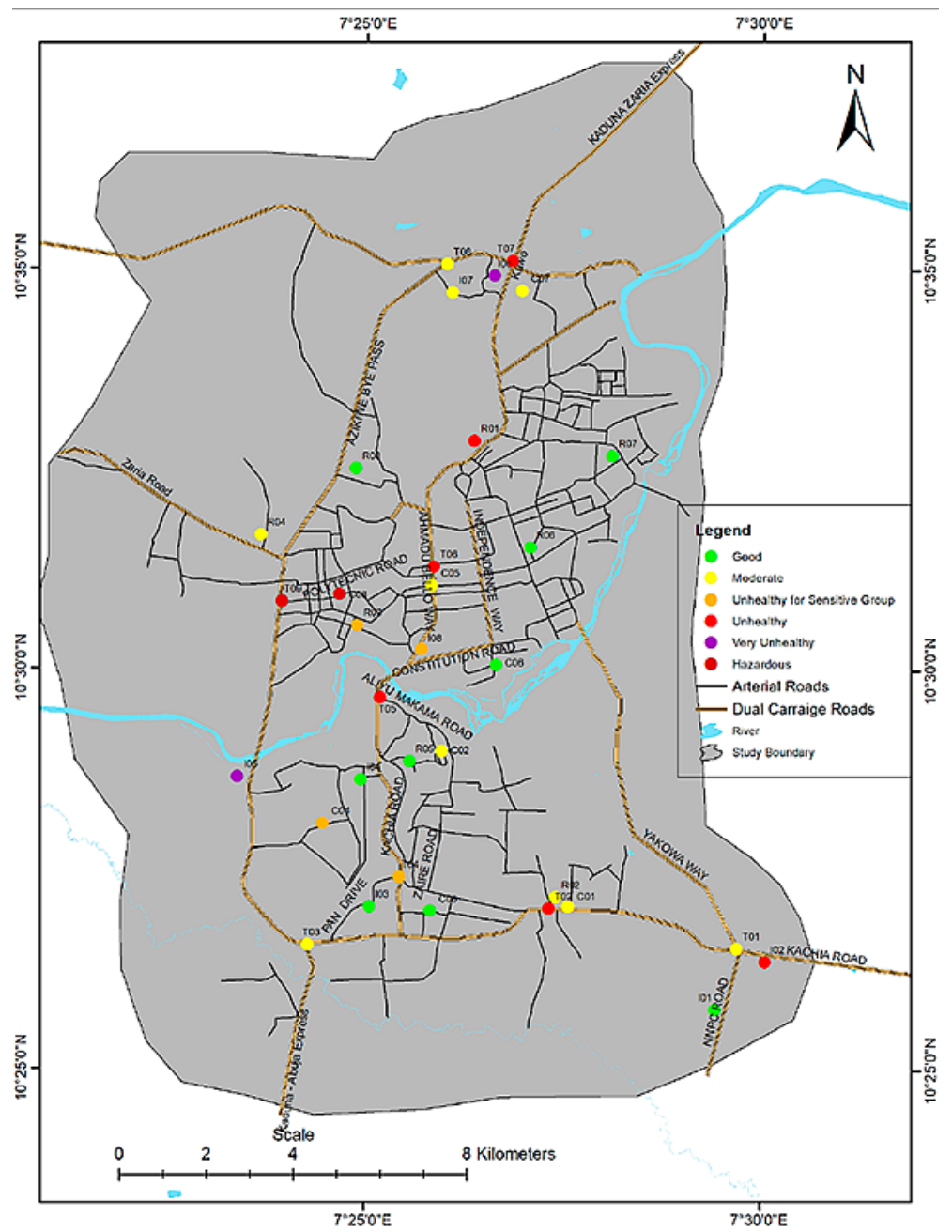

Figure 10. Spatial Analysis of $\mathrm{SO}_{2} \mathrm{AQI}$ for Harmattan Weather Basedon USEPA Standard Source: Fieldwork (2019)

The emission level of SO2 is safe in the commercial area except for Kasuwan Barchi which shows a very unhealthy and hazardous AQI base on NESREA and USEPA standards respectively. Equally the emission level of the $\mathrm{SO} 2$ in residential areas are safe except for Ungwan Shanu area which shows an unhealthy AQI base on USEPA standard and unhealthy for sensitive group base on NESREA standard.

$\mathbf{P M}_{10}$ : The results reveal that the AQI for $\mathrm{PM}_{10}$ during the harmattan weather in Kaduna Metropolis ranges from good to hazardous. This result agrees with the submission of Saniei et al. (2016) and Chizoruo (2017), who's finding equally shows an AQI which ranges from moderate to hazardous. The study findings base on NESREA standard reveals that about $40 \%$ of the sites are safe, while USEPA standard shows that only about $25 \%$ of the sites to be safe, which are randomly distributed in both the northern 


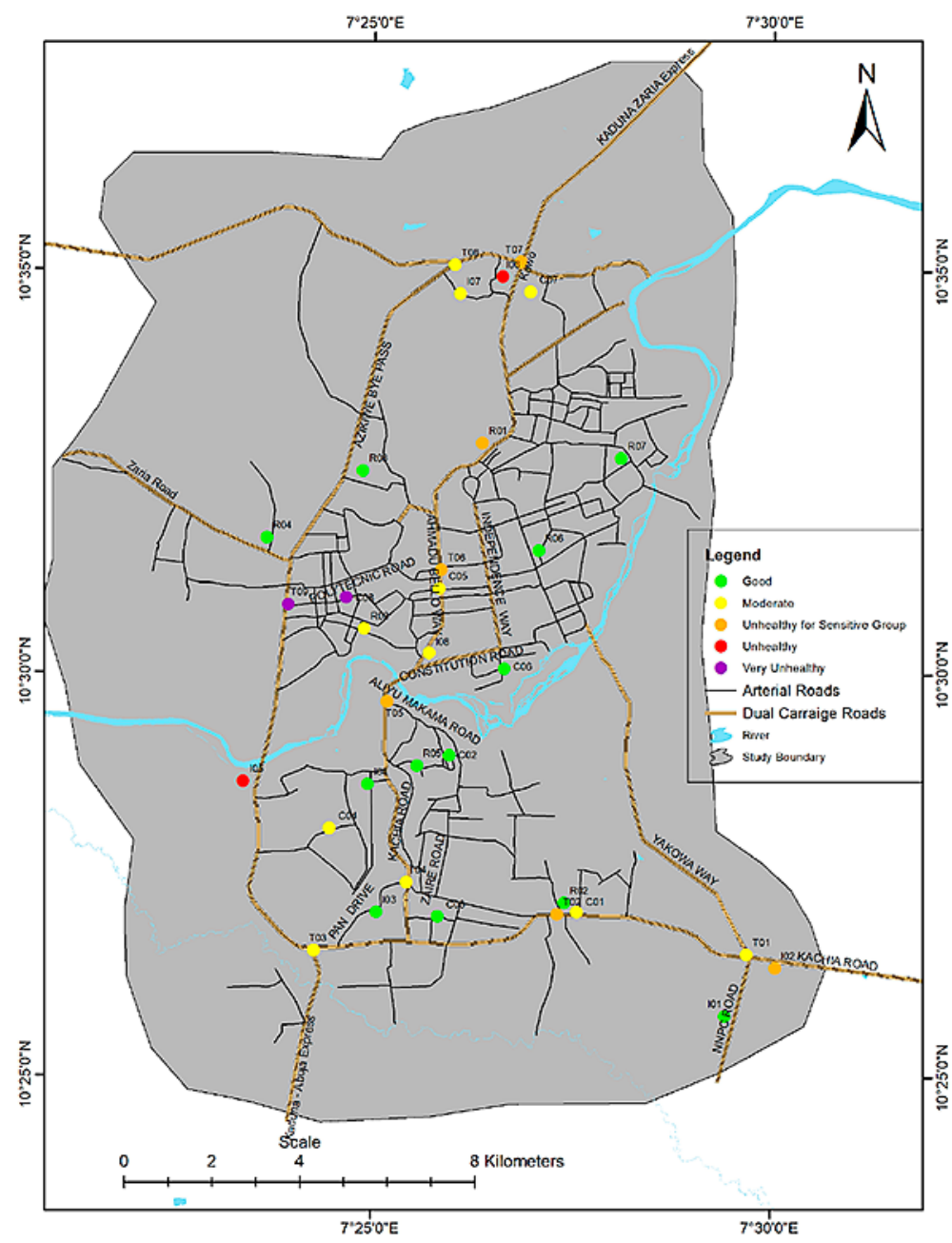

Figure 11. Spatial Analysis of $\mathrm{SO}_{2} \mathrm{AQI}$ for Harmattan Weather base on NESREA Standard Source: Fieldwork (2019)

and southern part of the metropolis. Also, 9.09\% and 30\% of the sites are unhealthy for sensitive group of people base on USEPA and NESREA standard respectively. Equally $27.27 \%$ and $15.15 \%$ of the sites are unhealthy base on USEPA and NESREA standard respectively. $18.18 \%$ of the sites are very unhealthy base on both the USEPA and NESREA standard. And a good number of the sites about $27.27 \%$ are hazardous base on USEPA standard, while the NESREA standard shows only 1 of the sites is hazardous, equally the hazardous sites are mostly found in the northern part of the metropolis. whereas, WHO standard shows that about $82 \%$ of the sites are hazardous and spatially distributed in both the northern and southern part of the metropolis. This implies that most of the sites are unsafe for human beings and equally affects the natural functioning of the environment. This aggress with the submission of Notardonato, Manigrasso, Pierno, Settimo, Protano, Vitali, ... and Avino, P. (2019) that particular matter emission is mostly 
as result of fossil fuel emission, and that of Emetere, (2016) which shows higher aerosols (particulate matter concentration during the dry harmattan weather in northern Nigeria cities mostly as result of the north east trade wind.

Thus, may cause people with heart disease to experience chest pain, palpitations, shortness of breath, and fatigue. people with existing lung disease may not be able to breathe as deeply or vigorously as they normally would. They may experience symptoms such as coughing and shortness of breath. Healthy people also may experience these effects, although they are unlikely to experience more serious effects. Further probe reveals that most of the traffic sites are hazardous base on WHO and USEPA standard, while NESREA standard shows that only Dustema junction is hazardous. Also, 25\% of the industrial sites are safe based on USEPA standard while NESREA standard shows more industrial sites $50 \%$ to be safe. Also, none of the commercial sites PM10 concen-

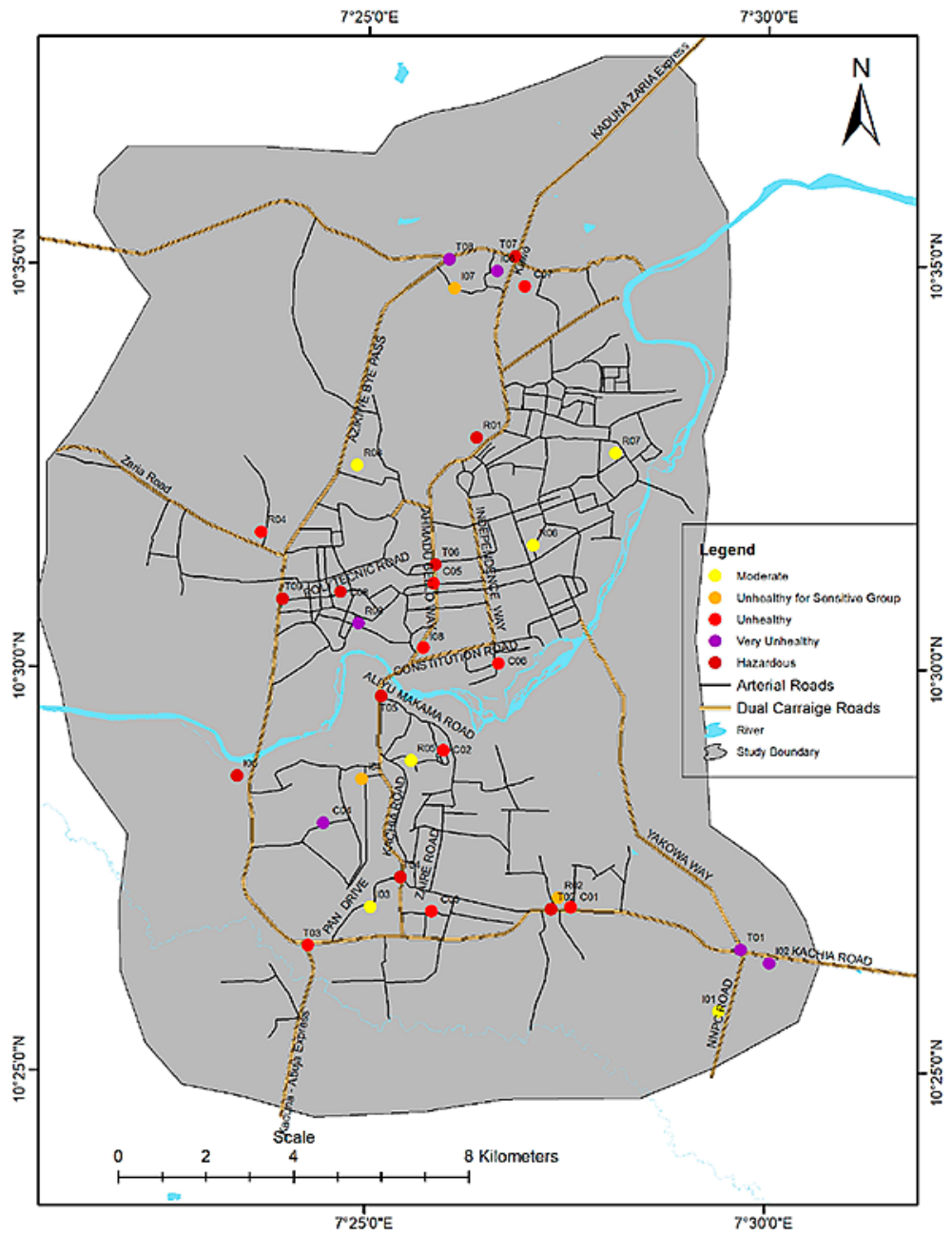

Figure 12. Spatial Analysis of $\mathrm{PM}_{10}$ AQI for Harmattan Weather base on USEPA Standard Source: Fieldwork (2019) 


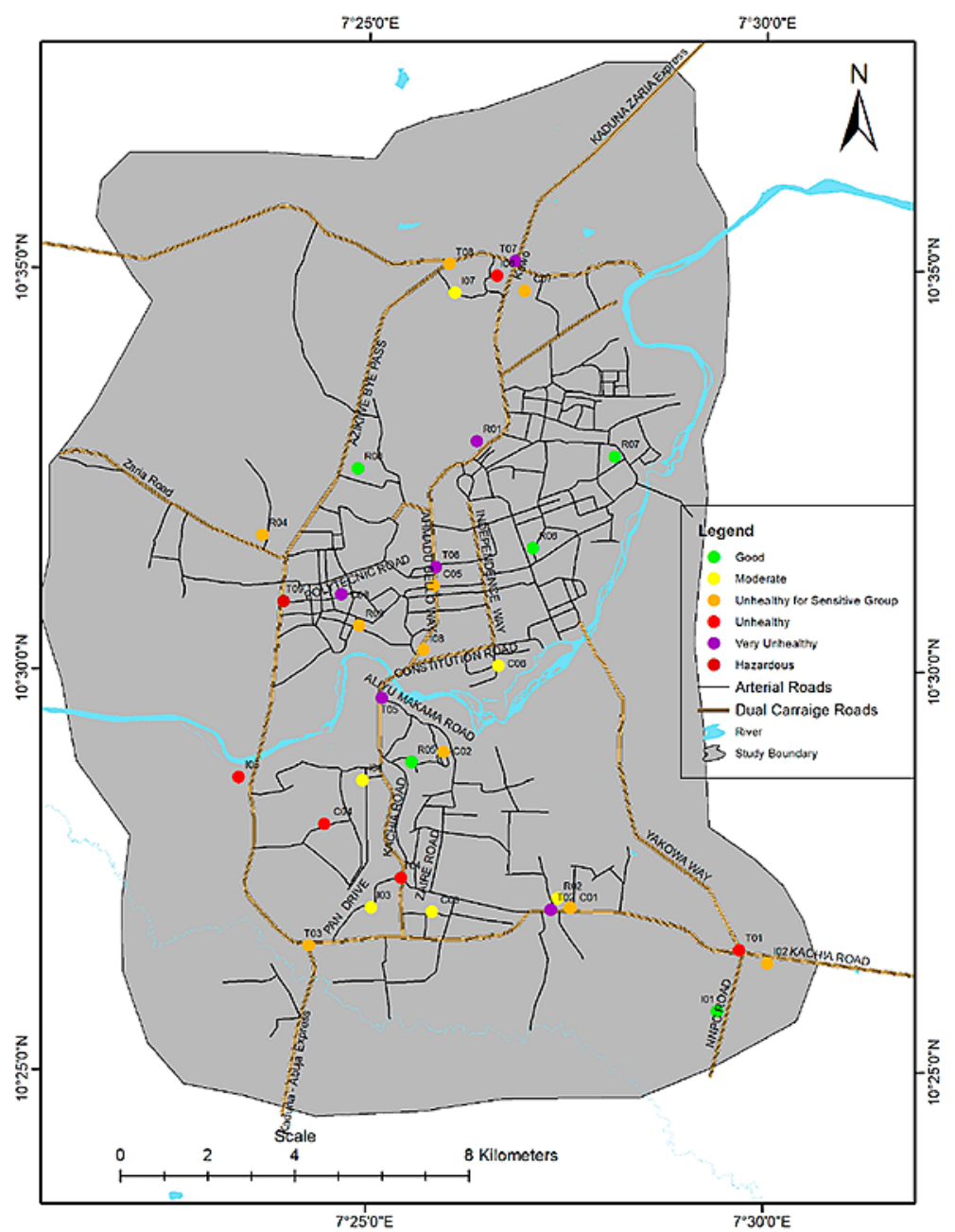

Figure 13. Spatial Analysis of $\mathrm{PM}_{10} \mathrm{AQI}$ for Harmattan Weather base on NESREA Standard Source: Fieldwork (2019)

tration is safe for human existence's base on USEPA standard, while NESREA standard shows that the AQI index in 2 of the commercial sites is moderately safe. Equally Base on NESREA standard the AQI for the residential sites are safe except for Ungwan shanu site which is very unhealthy, whereas only the GRA sites AQI is safe base on USEPA standard. also, more of the unsafe sites are found in the northern part of the metropolis.

\section{CONCLUSION}

The findings from this study shows that air quality in Kaduna metropolis have deteriorated with Air Quality Index ranging from good to hazardous. Residence and commuters are exposed to this level of pollution by chemicals such as $\mathrm{CO}, \mathrm{SO}_{2}$ and PM10 
which are detrimental to human wealth being. Understanding of the spatial distribution of the implication of the AQI in the metropolis will aid residence and commuters plan their daily activities in manners that will be less detrimental to their wealth being and will equally aid in the planning for the control of toxic emission in Kaduna metropolis.

CO has $57.57 \%$ and $24.24 \%$ of the sites AQI ranging from unhealthy to hazardous based on WHO/USEPA and NESREA standards respectively. Equally $\mathrm{SO}_{2}$ has about $91 \%, 34.23 \%, 42.42$ of the sites AQI ranging from unhealthy to hazardous base on WHO, USEPA and NESREA standards respectively. $\mathrm{PM}_{10}$ has $75.76 \%$ and 18.18 of the sites AQI as hazardous base on WHO and USEPA standards, whereas none of the sites AQI is hazardous base on the NESREA standard. further analysis shows that the northern part of the metropolis has more sites with unhealth AQI than the southern part of the metropolis. The temporal analysis for the seasonal variations shows that Air Quality Index for the concentration of $\mathrm{CO}$ and $\mathrm{SO}_{2}$ shows more unhealthy side in the raining season than in the dry harmattan weather. However, the AQI for $\mathrm{PM}_{10}$ shows more unhealthier sites during the dry harmattan weather than during the raining season. Also, the study concludes that most of the unhealthy AQI are within traffic areas, whereas, most of the healthy sites were within residential areas. This shows that most of the unhealthy $\mathrm{AQI}$ are as result of the burning of fossil fuels within the metropolis. thus, the need to strongly enforce existing laws guiding ambient emission in Kaduna metropolis and also to provides a more efficient transport system that will make the use of private vehicles less attractive will go a long way in improving the air quality index of the metropolis.

\section{ACKNOWLEDGEMENT}

We acknowledge Yahaya A. Aliyu for providing us with portable monitors used in this study and for his support. We also appreciate field assistance used in data acquisition. We are grateful to the anonymous reviewers for their efforts.

\section{REFERENCES}

Abaje, I.B, Ati, O. F and Ishaya, S. (2009). Nature of Portable Water Supply and Demand in Jema'a Local Government Area of Kaduna State, Nigeria, Research Journal of Environmental and Earth Sciences, 1(1), 16 - 21

Abam, F.I. and Unachukwu, G.O. (2009). Vehicular Emission and Air Quality Standards in Nigeria, European Journal of Scientific Research, 1(4): 550 - 560

Adedeji, O.H, Olasumbo, O. and Oluwaseun, T.O. (2016). Mapping of Traffic-Related Air Pollution Using GIS Techniques in Ijebu-Ode, Nigeria, Indonesian Journal of Geography, 48(1), $73-83$

Akpu, B. (2012). An Analysis of Spatio-Temporal Gowth of Kaduna Metropolis and Its Enviromental Consequences in Kaduna, Nigeria, Unpublished PhD Thesis, Department of Geography, Bayero University, Kano. 
Anjoneyulu, Y. (2005). Introduction to Environmental Science, BS Publications, Hyderabad India.

Aremu, J.K. (2014). The Language of Metrology, Cee Kay Bee printers, VV4, Keffi Road, Kaduna, Nigeria.

Attah, A.A. (2015). Impact of Vehicular Traffic Emissions on Ambient Air Quality in Kaduna Metropolis, Unpublished MSc Dissertation, Department of Water Resources and Environmental Engineering, Faculty of Engineering, Ahmadu Bello University, Zaria.

Augustine, C. (2012). Impact of Air Pollution on the Environment in Port Harcourt, Nigeria, Journal of Environmental Science and Water Resources, 1(3), 46 - 51.

Baumbach, G., Vogt, U., Hein, K.R.G., Oluwole, A.F., Ogunsola, O.J., Olaniyi, H.B. and Akeredolu, F.A. (1995). Air Pollution in a Large Tropical City with a High Traffic Density-Results of Measurement in Lagos, Nigeria, The Science of the Total Environment, 169 (1-3), 25-31.

Bortnick, S.M., Coutant, B.W. and Eberly, S.I. (2002). Using Continuous PM2.5 Monitoring Data to Report an Air Quality Index, Journal of Air Waste Management Association, 52(1), 104-112.

Cheng, W., Chen, Y., Zhang, J., Lyons, T.J., Pai, J. and Chang, S., (2007). Comparison of Revised Air Quality Index with the PSI and AQI Indices, Science of the Total Environment, 382 (2-3), 191-198.

Chizoruo, I.F., Iheanyichukwu, O.A., Chukwuemeka, N.P. and Ikechukwu, A.J. (2017). Ambient Air Quality Assessment of Orlu, Southeastern, Nigeria, Journal of Applied Science, 17, 441-457

David, R.L. and Frederikse, H.P.R. (1997). Handbook of Chemistry and Physics, 28th Edition, Sage Publishers, India.

Delay, A. and Zanetti, P. (2007). An Introduction to Air pollution- Definitions, Classifications, and History, In Zanetti, P., Al-Ajmi, D. and Al-Rashied, S. (eds), Ambient Air Polluiton, The Arab School for Science and Technology (ASST).

Emetere, M. E. (2016). Statistical examination of the aerosols loading over Mubi-Nigeria: The satellite oobservation analysis. Geographica Pannonica, 20(2), 62-69.

Fedra, K. (1999). Urban Environmental Management: Monitoring, GIS, and Modeling, Computers, Environment and Urban Systems, 23, 443-457.

Fischer, P., Hoek, G., Brunekreef, B.,Verhoeff, A. and Van-Wijnen, J. (2003). Air Pollution and Mortality in the Netherlands; are the Elderly More at Risk? The European Respiratory Journal, SupplementI, 40, 34 - 38.

Garg, S. K., Garg, R. and Garg, R. (2006). Environmental Science and Ecological Studies, Delhi, Khanna Publishers, Hyderabad, India.

Gupta, A.K., Karar, K., Ayoob, S. and John, K. (2008). Spatio-Temporal Characteristics of Gaseous and Particulate Pollutants in an Urban Region of Kolkata, India, Atmos. Res, 87 (1), 3-15.

Gupta, P., Christopher, S.A., Wang, J., Gehrig, R., Lee, Y. and Kumar, N. (2006). Satellite Remote Sensing of Particulate Matter and Air Quality Assessment over Global Cities, Atmospheric Environment, 40(30), 5880 - 5892. 
Jorgensen, S.E. and Bendoricchio, G. (2001). Fundamentals of Ecological Modelling, Amsterdam: Elsevier.

Ladan, S.L. (2013). Examining Air Pollution and Control Measures in Urban Centers of Nigeria, International Journal of Environmental Engineering and Management, 4 (6), $621-628$.

Maquire, D.J., Batty, M. and Goodchild, M.F. (2005). GIS, Spatial Analysis and Modeling, Redlands: ESRI Press.

Matejicek, L. (2011). Spatio-temporal analysis of environmental pollution in urban areas: A case study of the environment in the city of Prague, 19th International Congress on Modelling and Simulation, Perth, Australia, 12-16 December. http://mssanz.org. au/modsim 2011

Mintz, D. (2009). Technical assistance document for the reporting of daily air quality the air quality index (AQI). US EPA Office of Air Quality Planning and Standards, Research Triangle Park, NC, USA.

Mohan M, and Kandya A, (2007). An analysis of the annual and seasonal trends of air quality index of Delhi, Environ Monit Assess 131, 267-77.

Murena, F. (2004). Measuring Air Quality Over Large Urban Areas: Development and Application of an Air Pollution Index at the Urban Area of Naples, Atmospheric Environment, 38, 6195 - 6202.

Mwenda, L.P. (2011). Geostatistical Analysis of Air Pollution Using Models, In Situ and Remote Sensed Data. MSc Thesis, University of Twente, Faculty of Geo-Information and Earth Observation, ITC, Enschede.

National Population Commission (NPC) (1991). Census Population of Nigeria, Federal Republic of Nigeria official Gazette, Lagos, the Federal Government Printers.

Notardonato, I., Manigrasso, M., Pierno, L., Settimo, G., Protano, C., Vitali, M., ... and Avino, P. (2019). The importance of measuring ultrafine particles in urban air quality monitoring in small cities. Geographica Pannonica, 23(4), 347-358.

NPC (2009). Federal Republic of Nigeria official Gazette, Lagos, the Federal Government Printers, 24 (94), 187.

Nwude, M.O., (2006). A Sustainable Option for Solid Waste Management in Kaduna Metropolis Unpublished M.Sc Thesis Ahmadu Bello University, Zaria, Kaduna.

Odigure, J.O. (1998). Safety Loss and Polluton Control in Chemical Process Industries, Jodigs and Associates, Minna, Nigeria, pp. 89-93.

Ogwu, F.A., Peter, A.A, Aliy, H.B. and Abubakar, N. (2015). An Investigative Approach on the Effect of Air Pollution on Climate Change and Human Health in the Niger Delta Region of Nigeria, International Journal of Scientific Research and Innovative Technology, 2 (5).

Olajire, A.A., Azeez, L. and Oluyemi, E.A. (2011). Exposure to Hazardous Air Pollutants Along Oba Akran Road, Lagos - Nigeria, Chemosphere, 84(8), 1044 - 1051.

Powe, N.A. and Willis, K.G. (2004). Mortality and Morbidity Benefits of Air Pollution $\left(\mathrm{SO}_{2}\right.$ and $\left.\mathrm{PM}_{10}\right)$ Absorption Attributable to Woodland in Britain, Journal of Environmental Management, 70, 119 - 28. 
QEPA (2001). Ambient Air Quality Monitoring in Queensland; 2001 Annual Summary And Trend http://www.epa.qld.gov.au/environmental_management/air/air_quality_ monitoring/air_quality_report. Accessed 10 June 2017.

Saniei, R., Zangiabadi, A., Sharifikia, M. and Ghavidel, Y (2016). Air quality classification and its temporal trend in Tehran, Iran, between 2002-2012, Geospatial Health, 11(2), Health Application in geospatial Science.

Smallbone K. (1998). Mapping ambient urban air pollution at the small area scale: a GIS approach. Unpublished PhD thesis, Department of Geography, University of Huddersfield. UK.

USEPA (2003). Guideline for Reporting Daily Air Quality, Air Quality Index (AQI), EPA454/k-03-002, Office of Air Quality Planning and Standards: Research Triangle Park, NC.

USEPA (2014). A Guide to Air Quality and Your Health, Air Quality Index, U.S. Environmental Protection Agency Office of Air Quality Planning and Standards Outreach and Information Division Research Triangle Park, NC.

Venners, S.A., Wang, B., Xu, Z., Schlatter, Y., Wang, L. and Xu, X. (2003). Particulate matter, sulfur dioxide and daily mortality in Changqing China, Environmental health perspectives, 111, $562-7$.

Wai, C.S. and Steven, L. (2007). Air Pollution: Business risk or competitive advantage, p.285.

Wang, Y.; Eliot, M.N. and Wellenius, G.A. (2014). Short-term changes in ambient particulate matter and risk of stroke: a systematic review and meta-analysis, J Am Heart Assoc; Vol 3.

WHO (World Health Organization), (2006). Air Quality Guidelines: Global Update 2005, World Health Organization, Geneva, p. 484.

Yusuf, A.K.,Oluwole, S., Abdusalam, O.I. and Adewusi, G.R. (2013). Spatial Patterns of Urban Air Pollution in an Industrial Estate, Lagos, Nigeria, International Journal of Engineering Inventions, 2 (4), 01 - 09.

Zeiler, M. (2010). Modeling our World, Redlands: ESRI Press.

\section{CONFLICTS OF INTEREST}

The authors declared no potential conflicts of interest with respect to the research, authorship, and/or publication of this article.

(C) 2020 by the authors. This article is an open access article distributed under the terms and conditions of the Creative Commons Attribution (CC BY) license (http://creativecommons.org/licenses/by/4.0/). 